\title{
Model-derived connectivity patterns along the western Iberian Peninsula: asymmetrical larval flow and source-sink cell
}

\author{
R. Nolasco ${ }^{1,2}$, J. Dubert ${ }^{1,2}$, C. P. Domingues ${ }^{1,3}$, A. Cordeiro Pires ${ }^{1,2}$, H. Queiroga ${ }^{1,3, *}$ \\ ${ }^{1}$ CESAM, Universidade de Aveiro, Campus Universitário de Santiago, 3810-193 Aveiro, Portugal \\ ${ }^{2}$ Departamento de Física and ${ }^{3}$ Departamento de Biologia, Universidade de Aveiro, Campus Universitário de Santiago, \\ 3810-193 Aveiro, Portugal
}

\begin{abstract}
Predicting the spatial and temporal patterns of marine larval dispersal and supply is a challenging task, requiring the use of novel approaches capable of capturing the inherent variability in the mechanisms involved. Biophysical models are emerging as important tools used to understand dispersal and recruitment of marine larvae on several scales, and are used here to investigate these problems in the Northeast Atlantic Iberian Upwelling system. We used a Regional Ocean Modelling System configuration coupled with an individual-based model in order to simulate diel vertical migration and estuary-reinvasion behaviours, growth and mortality of larvae of the common shore crab Carcinus maenas. With this simulation we aimed to hindcast coast-wide connectivity patterns under the atmospheric and river flow forcings of the years 2001 to 2009. In a previous study, this model had been shown to produce time series of larval supply to a single population, at daily frequencies, that were strongly correlated with observed time series. In the current application, the model predicts that along-shore advection of larvae is variable from year to year; is correlated with the annual North Atlantic Oscillation index, which reflects the strength and persistence of equatorward winds; and is usually asymmetric, with a predominant equatorward transport. The model also predicts a source-sink cell located between the MurosNoia and Mondego estuaries, where populations in the north consistently act as net sources of larvae supplying net sink populations to the south. This source-sink cell appears to be related to the existence of habitat gaps, coast geometry and an oceanographic retention effect associated with upwelling dynamics.
\end{abstract}

KEY WORDS: Population connectivity $\cdot$ Larval dispersal $\cdot$ Modelling $\cdot$ Iberian Peninsula $\cdot$ ROMS · Carcinus maenas

Resale or republication not permitted without written consent of the publisher

\section{INTRODUCTION}

Many fish and invertebrate species occurring in coastal waters of the world have a bi-phasic life cycle, where a sessile or sedentary benthic adult produces a planktonic larva. The processes of larval dispersal and mortality are thought to play a fundamental role on population dynamics of these marine species (Roughgarden et al. 1985), by setting the geographical scale of populational units (Cowen et al. 2000, Sale \& Kritzer 2003) and controlling the level of larval supply to the adult habitat (Morgan 1995, Caley et al. 1996). Many marine populations are, therefore, demographically open, partly depending on processes that occur elsewhere influencing the production, movement and survival of dispersers. Understanding how networks of populations (i.e. metapopulations) are connected by dispersal is, therefore, crucial for understanding gene flow, evolution, biodiversity patterns and resilience of marine 
populations, as well as for developing effective management measures capable of providing local benefits in terms of resource yield and biodiversity conservation (Levin 2006).

Empirical observations using genetic (e.g. Hellberg 1994, Doherty et al. 1995, Shulman \& Bermingham 1995, Sotka et al. 2004, Domingues et al. 2010) and geochemical site-specific tags (e.g. Swearer et al. 1999, Sale \& Kritzer 2003, Becker et al. 2007) indicate that moderate levels of larval exchange typify many marine populations over a range of spatial scales. Yet, the minute size of the larvae, the large mortality rates and the unbounded nature of dispersal pathways in the marine environment create logistic difficulties in describing the origin and destination of individual larvae and obtaining empirical measures of dispersal and connectivity.

To overcome these difficulties, numerical models of ocean circulation coupled to individual models simulating larval biology (biophysical models) have been increasingly used to describe larval dispersal, supply and connectivity of marine populations. Biophysical models provide a simulation environment integrating abiotic variability of the marine environment with biological processes at multiple temporal and spatial scales (Morgan 1995, Caley et al. 1996, Miller 2007, Werner et al. 2007, Metaxas \& Saunders 2009). In several applications, biophysical models of larval dispersal have been used to provide theoretical expectations of the effects of various forcing factors on transport (Botsford et al. 1994, Cowen et al. 2000, Siegel et al. 2003, Levin 2006). These studies often assume a spatially homogeneous stochastic flow and passive dispersal (Largier 2003). Under these conditions, the position of a particle at time $t$ depends on a mean velocity (i.e. advection) and on a variance of the stochastic processes (i.e. eddy diffusion). This simple advective-diffusive paradigm is not more than a null model and results in a Gaussian dispersal kernel describing the spatial distribution of settling particles. More realistic applications have used models that include topography and stratification, coupled to different types of particle behavioural schemes, in order to resolve the interactions among oceanographic and biological processes determining larval dispersal patterns. When properly fine-tuned to species-specific biological traits and compared against field observations, these models have provided useful insights into the factors that control observed spatial distributions of adults (Incze et al. 2000, James et al. 2002), recruits (Pfeiffer-Herbert et al. 2007) or larvae (Ellien et al. 2004, Paris \& Cowen 2004, Peliz et al. 2007b, Erftemeijer et al. 2009).
Recently, biophysical models have also been used as a basis for seascape genetic models and applied to explain phylogeographic patterns and spatial distributions of allele frequencies (Galindo et al. 2010).

The use of numerical biophysical models of larval dispersal to predict connectivity patterns in benthic species with a bi-phasic life cycle should be used with care (Werner et al. 2007). Difficulties still impinging the widespread use of models to this end result from the complexities of oceanographic circulation, which spans a wide range of spatial scales and includes several non-linear processes such as internal and surface tides, waves or turbulent mixing, from the variability of the biological processes themselves such as behaviour, feeding and mortality, and from technical issues related to parameterization of sub-grid processes and nesting of domains with different grid dimensions. These complexities have prompted several authors to apply stochastic modelling methods to the problem of marine larvae dispersal (Mitarai et al. 2008, Siegel et al. 2008). However, several important aspects of larval dispersal variability over a variety of space and time scales appear to be correlated with ocean flow (Largier 2003, Siegel et al. 2003, Pineda et al. 2007), and the use of hydrostatic models such as the Regional Ocean Modelling System (ROMS) is appropriate in these cases.

In the present study, we generated coast-wide connectivity matrices and dispersal kernels for a coastal invertebrate along the Iberian Peninsula for 9 consecutive years. We used a numerical biophysical model in order to understand how patterns of connectivity change, on an inter-annual basis, in response to mid- to long-term changes in atmospheric forcing. Our model uses ROMS coupled to an Individual Based Model (IBM) simulating temperaturedependent growth, physiologic mortality due to suboptimal environmental conditions and diel vertical migration behaviour of larvae of the common shore crab Carcinus maenas. The model has been previously validated elsewhere (Domingues et al. 2012). In the Domingues et al. (2012) study, the performance of the model to hindcast the dispersal processes during the larval phase of $C$. maenas was assessed by comparing time series of expected supply of competent larvae to the Ria de Aveiro, an estuary located in the northwest Portuguese coast (see Fig. 1), generated at daily frequencies during the larval season of 2 consecutive years, against measurements of supply made at the same frequencies. Cross-correlations between observed and expected supply time series were significant and ranged from 0.34 to 0.81 at -6 to $+5 \mathrm{~d}$ time lags, depending on growth rate and mor- 
tality. The performance of the model was mainly associated with its ability to describe supply events associated with wind-driven circulation, which is the most important component of shelf circulation in this coastal upwelling region (Relvas et al. 2007). Moreover, the model predicted cross-shelf larval distributions that were significantly correlated $(\mathrm{r}=0.82, \mathrm{p}<$ 0.001) with observed concentrations (Queiroga 1996), as well as average dispersal distances during planktonic development ranging from 57 to $183 \mathrm{~km}$. These predicted dispersal distances are remarkably consistent with estimates of dispersal distance based on the species' annual rate of range expansion in invaded regions (Shanks et al. 2003).

In the present study, we used a configuration of our biophysical model that employed a diel vertical migration (DVM) scheme inferred from observations made on the Portuguese shelf, as well as growth and mortality rates derived from laboratory experiments (i.e. the Lagrangian offline model). These options reflect a conservative approach relative to other possible growth and mortality rates, but which are unsubstantiated by available data. This configuration of the model produced correlations between observed and predicted supply ranging from 0.58 to 0.66 at time lags smaller than $\pm 5 \mathrm{~d}$ (Domingues et al. 2012). The predictions of the model now reported strongly suggest several spatial and temporal patterns of connectivity, related to the wind-driven circulation around the Iberian Peninsula, the availability of habitat and the configuration of the coastline, some of which are non-trivial. The model predicted a general southward advection of larvae, consistent with the main patterns of circulation in the region; a recurrent source-sink cell located in the northwest coast, related to habitat gaps and an oceanographic retention effect and a barrier to northward dispersal between the Tejo and the Mondego Rivers.

\section{METHODS}

\section{The environment}

The west coast of the Iberian Peninsula is located on the northernmost limit of the Eastern North Atlantic Upwelling Region, running for about $700 \mathrm{~km}$ along a north-south direction. At the north and south extremes, near Capes Finisterre and S. Vicente, the coast veers east and extends for a few hundreds of kilometres. Several estuarine systems and rias occur along the west Iberian coast, and stretches of sandy shores alternate with rocky shores on scales of kilo- metres to a few tens of kilometres. This geological setup provides a conceptually interesting environment to test population connectivity in coastal species because it effectively demarcates local populations along a coast that is approximately linear, with only a few coastal islands and shallow bays.

Circulation off the west Iberian coast (Peliz et al. 2005, Relvas et al. 2007) is mostly controlled by the interaction of the Iberian Poleward Current (IPC) with the upwelling/downwelling circulation driven by along-shore winds and with the Western Iberian Buoyant Plume (WIBP). The IPC flows over the slope. It results from a meridional pressure gradient with higher values to the south, which causes an eastward geostrophic advection that is diverted to the north when it encounters the slope (Peliz et al. 2003). The coastal waters over the shelf are under the influence of the along-shore wind circulation (Fiúza 1983, Frouin et al. 1990, Haynes et al. 1993). During winter, the flow is predominantly in the northward direction, because the poleward flow along the slope is reinforced and extends to the shelf in response to southerly winds associated with the passage of cold fronts. Southward flow prevails during spring and summer because of the dominance of northerly, upwelling-favourable winds. This wind-driven southward current flows over the poleward slope current and pushes it offshore (Peliz et al. 2003). The WIBP originates from runoff of the many freshwater sources in the area. It is perceived as a lens of low salinity water (Peliz et al. 2002) persisting year round, albeit less conspicuous during summer. The WIBP interacts in a complex manner with the winddriven circulation, being contained in the inner shelf by downwelling winds and stretching offshore during upwelling periods.

Although upwelling filaments (Haynes et al. 1993, Huthnance et al. 2002) and the dynamics of the WIBP (Peliz et al. 2002) may be responsible for the offshore transport of larvae, both the upwelling front (Roughgarden et al. 1991) and species-specific larval behaviours (Poulin et al. 2002, Shanks \& Brink 2005, Marta-Almeida et al. 2006) may constitute obstacles to offshore dispersal. Therefore, the scale of connectivity among populations of coastal species along the west coast of the Iberian Peninsula is probably regulated by the along-shore circulation over the shelf driven by upwelling and downwelling winds (Queiroga et al. 2006).

The oceanography of the north and south coasts of the Iberian Peninsula is not as well studied, but it appears that they are connected on a seasonal basis with the west coast. During winter, the IPC and the 
buoyant plumes flow around the Finisterre Cape, invading the Bay of Biscay. At the same time, the Gulf of Cadiz Countercurrent (Relvas \& Barton 2005) and the Mediterranean Outflow promote water transport around the S. Vincent Cape into a poleward direction. During the summer, the reverse occurs. On the south corner, the upwelling dynamics and the Gulf of Cadiz Current (Peliz et al. 2007a) promote transport to the Gulf of Cadiz, whereas at the north corner water masses are dragged from the Bay of Biscay.

\section{Biological model}

Our biological model was developed to mimic the early life history traits of the portunid shore crab Carcinus maenas (L.). The shore crab is amongst the most characteristic and successful crustaceans that inhabit European coastal waters. Its wide geographical distribution and local high abundance place $C$. maenas as a species of prime ecological importance. C. maenas lives mostly in estuarine systems in southern Europe. During the reproductive season, which occurs from winter to early summer, berried C. maenas females move to the lower estuary where free swimming planktonic larvae (first zoeae) hatch during nocturnal ebb tides. Hatching during night time ebb is thought to maximise larval seaward transport by the strong ebb currents, as well as to reduce predation pressure on both larvae and females (Queiroga et al. 1994). This behaviour results in pulses of abundance of first zoeae that last for 3 to $5 \mathrm{~d}$ and recur at fortnight intervals (Queiroga et al. 1994, 1997). C. maenas larval phase comprises 4 planktotrophic zoeae and 1 megalopa, which is the stage that reinvades estuaries and metamorphoses into the first benthic crab stage (Rice \& Ingle 1975). Planktonic development lasts from 4 to $6 \mathrm{wk}$, depending on water temperature (Dawirs 1985, Mohamedeen \& Hartnoll 1990, Nagaraj 1993). At $20^{\circ} \mathrm{C}$, the duration of the different larval stages increases from $3 \mathrm{~d}$ in zoea-1 to $5 \mathrm{~d}$ in zoea- 4 , and the megalopal stage lasts 9 to $10 \mathrm{~d}$. At $15^{\circ} \mathrm{C}$, the zoeal stages require 5 to $8 \mathrm{~d}$ to moult, and the megalopae over $14 \mathrm{~d}$ (Mohamedeen \& Hartnoll 1990). At $6^{\circ} \mathrm{C}$, shore crab larvae are unable to moult. C. maenas larvae display a diel vertical migration behaviour in coastal waters (Queiroga et al. 1997, dos Santos et al. 2008) and their dispersal pathways deviate strongly from expectations based on assumptions made by passive dispersal models (Marta-Almeida et al. 2006).

Carcinus maenas forms large populations in estuaries and rocky shores in European coastal waters, with densities in this latter habitat decreasing with increasing exposure (Crothers 1970). Towards the southern end of its range, estuarine populations are still very important, especially in estuaries with large intertidal mudflats and seagrass beds (e.g. Gomes 1991, Queiroga 1995, Neves et al. 2007, Almeida et al. 2008), but the species is rare or absent in exposed rocky shores, probably due to intense competition with, or predation by, grapsid crabs that are common southward of Brittany (Flores \& Paula 2001). The species is also abundant in the middle and upper reaches of Galician Rias (e.g. Junoy \& Viéitez 1990, Cacabelos et al. 2010), and may also be frequent in the protected rocky shores downstream. Due to the lack of comparable data and of the geomorphological differences between Portuguese estuaries and Galician Rias, we did not attempt to model larval production as a function of population size or any of its proxies (e.g. system's area). Therefore, the patterns described here depend exclusively on the oceanography and on larval biology, but they suggest hypotheses about spatial and temporal patterns of dispersal and connectivity that may be tested in the future with other methodologies.

\section{Oceanographic model}

The simulations were conducted using a 3D freesurface, terrain-following primitive equation hydrostatic model configurable for fully realistic regional applications, based on ROMS (Shchepetkin \& McWilliams 2005). The present configuration represents an improvement and extension of the configuration used by Peliz et al. (2007a) and Oliveira et al. (2009) to the Atlantic margin of the Iberian Peninsula, and is identical to that used by Domingues et al. (2012) to describe the links between dispersal and supply of Carcinus maenas larvae in the same area. The reader is addressed to these studies (Peliz et al. 2007a, Oliveira et al. 2009, Domingues et al. 2012) for further details.

Two grids were used to resolve the circulation of the Iberian margin (Fig. 1): a first domain grid (FD, Fig. 1A), with a resolution of $1 / 10^{\circ}$ (ca. $10 \mathrm{~km}$ ), from $32^{\circ} \mathrm{W}$ to $0.5^{\circ} \mathrm{W}$ and $30^{\circ} \mathrm{N}$ to $48^{\circ} \mathrm{N}$. The FD was used to provide initial and boundary conditions, through offline nesting, to the large domain (LD, Fig. 1B). The LD has a horizontal resolution of $1 / 27^{\circ}$ (i.e. a mean resolution of $3.1 \mathrm{~km}$ ) and 60 vertical levels, including the western Iberian margin, from the Gulf of Cadiz at $34.5^{\circ} \mathrm{N}$ to the Bay of Biscay at $45.5^{\circ} \mathrm{N}$, and from $12.5^{\circ} \mathrm{W}$ to the Strait of Gibraltar at $5.5^{\circ} \mathrm{W}$. The LD covers an 


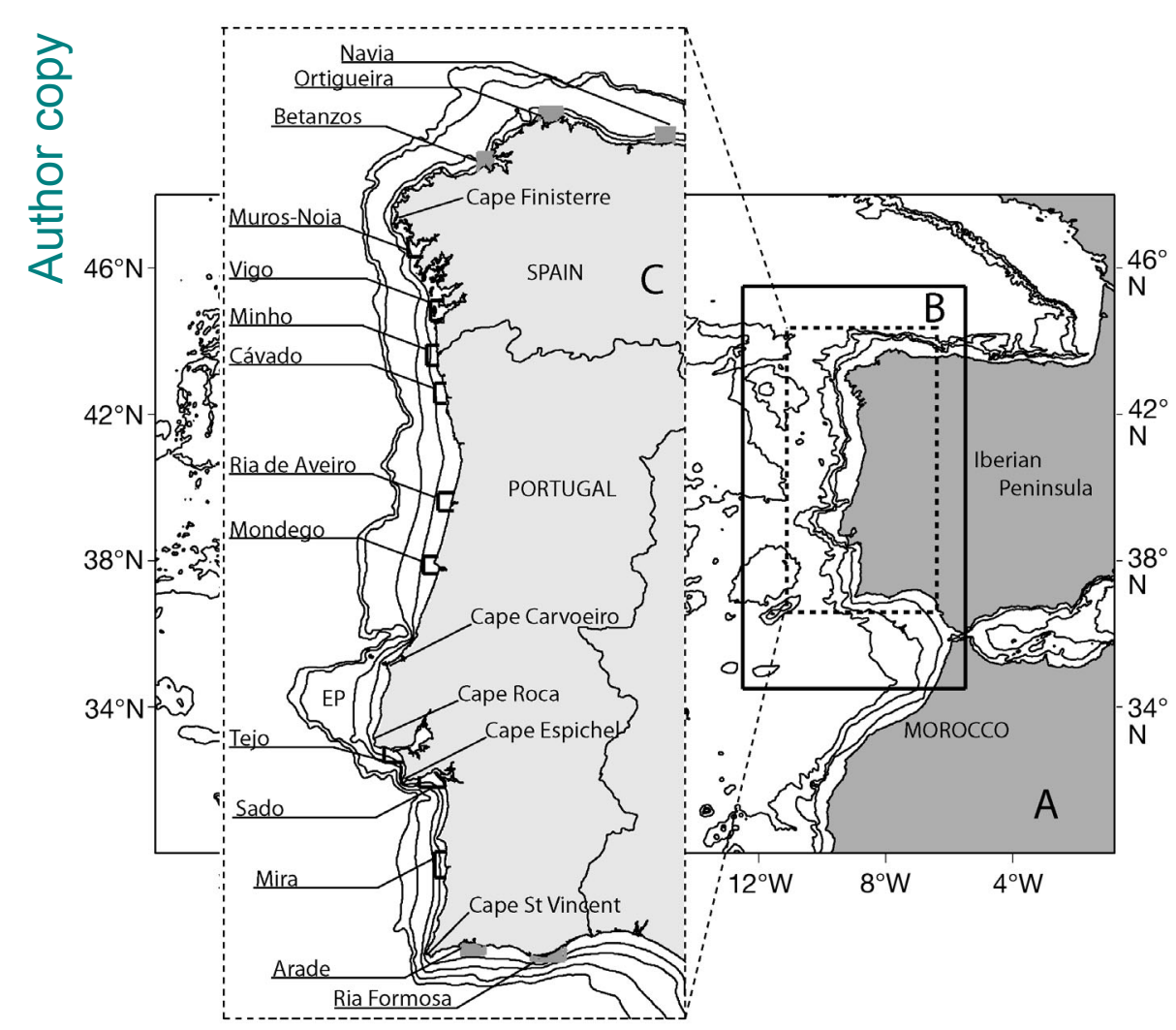

Fig. 1. Map of the study zone and model domains. (A) first domain (FD); (B) large domain (LD); (C) location of estuaries used in the model showing the shelf area adjacent to each estuary where larvae were emitted and recruited. $\mathrm{EP}=$ Estremadura Promontory

area of $\sim 1300 \times 600 \mathrm{~km}$ and constitutes the target domain used for the dispersal simulations. The FD was first initialized from rest using monthly temperature and salinity climatologies from the World Ocean Atlas 2005 (WOA05; Conkright et al. 2002) at the boundaries. After a 4-yr spin-up with the Comprehensive Ocean-Atmosphere Data Set (COADS; da Silva et al. 1994), realistic forcing at the surface was started. This forcing consisted of the NCEP2 air-sea fluxes (www.ncep.noaa.gov) and QuikSCAT reanalysed satellite winds (cersat.ifremer.fr) for the period 2001 to 2009 , with a spatial resolution of $0.5^{\circ}$. Forcing of the LD was the same as for the FD, ensuring consistency of forcing for both domains and avoiding problems at the boundaries. For the target domain LD, the Mediterranean Undercurrent (MU), originating from the Strait of Gibraltar and flowing along the southwest and west margins of the Iberian Peninsula, was imposed by a boundary inflow/outflow condition at the Strait of Gibraltar (Peliz et al. 2007a). The inflow of freshwater to the ocean, originating from the main rivers of the region, was included in the form of realistic river outflow (pro- vided by INAG, Water Institute of Portugal) when available. When there were no registers of river outflow during a period of time, a climatological value for seasonal river outflow was imposed. The outputs of the model, consisting of temperature, salinity and $3 \mathrm{D}$ velocity fields, were stored every $4 \mathrm{~h}$ in order to be used for the Lagrangian model described below.

\section{Lagrangian offline model}

In order to simulate hatching, behaviour and growth of Carcinus maenas larvae an Individual Based Model (IBM), similar to that used in the Domingues et al. (2012) study, was coupled to ROMS using ROFF (Carr et al. 2007). ROFF is a drifter-tracking code that simulates larval trajectories from stored ROMS velocity and hydrological fields.

The drifter-tracking code simulates larval trajectories from stored ROMS velocity and hydrological fields using a high order predictor-corrector scheme to integrate the motion equation $\mathrm{d} X / \mathrm{d} t=U_{\mathrm{ROMS}}(X, t)$, with $X$ being the position vector $(X, Y, Z)$, and $U_{\text {ROMS }}$ being the modelled 3D velocity vector over time, given an initial condition $X\left(t_{0}\right)=X_{0}$. The time step used in this Lagrangian model, $\mathrm{d} t$, is $300 \mathrm{~s}$. In addition to the advection generated by the model velocities, the particle movements included random velocities in the vertical direction, which were used to parameterize unresolved turbulent processes. A DVM scheme inferred from Queiroga (1996) and dos Santos et al. (2008) was also explicitly introduced in the model. The DVM scheme consisted of forcing the larvae to drift at depth between 06:00 $\mathrm{h}$ and 20:00 $\mathrm{h}$, and near the surface between 22:00 $\mathrm{h}$ and 04:00 $\mathrm{h}$, every day, while during the remaining periods the larvae migrated between the surface and the deep levels (defined as the bottom layer of the model if the local depth is shallower than $60 \mathrm{~m}$, or $60 \mathrm{~m}$ if the local depth is deeper).

In order to simulate hatching patterns, a set of 225 virtual larvae were released every fortnight during nocturnal ebb in the surface layer, near each of 14 estuarine systems (Navia, Ortigueira, Betanzos, Muros-Noia, Vigo, Minho, Cávado, Ria de Aveiro, 
Mondego, Tejo, Sado, Mira, Arade and Ria Formosa; Fig. 1), during the species larval season (February to July) of 2001 to 2009. These years were chosen as a compromise between availability of forcing data, inclusion of a large enough period encompassing the variability of the Iberian coast oceanography and computational time required. The position, temperature, velocities and age of a total number of 37800 particles per year $(225$ larvae per estuary $\times 12$ release periods $\times 14$ estuaries; henceforth referred to as either particles or larvae) were stored with a time step of $2 \mathrm{~h}$. To decrease computation time, we only used estuaries separated by at least $40 \mathrm{~km}$. Since estuarine inlets were not conveniently represented by the model, we released and recruited larvae in an area of the shelf adjacent to each estuary (approximate $12 \times 12 \mathrm{~km}$ ), which roughly corresponds to the area of the influence of the estuarine plume, and defined supply to the estuaries as the number of competent lavae that crossed that respective area (Fig. 1). Tides were not used in the model because previous work has shown that tidal currents do not affect the net horizontal advection of larvae that undergo DVM over the west Iberian shelf (Marta-Almeida \& Dubert 2006).

Temperature-dependent planktonic larval duration (PLD) and mortality were modelled pooling information from laboratory studies where larvae were reared without substrate (Mohamedeen \& Hartnoll 1990, Nagaraj 1993). The proportional effects of temperature on PLD, and of temperature and salinity on mortality, based on the time a larva was exposed to a specific temperature in the case of PLD, or to a specific combination of temperature and salinity in the case of mortality, were estimated by linearly interpolating between the laboratory data for each larval stage. Age and the probability of death were assessed at each time step of the Lagrangian model. Larvae were killed randomly based on the proportional death rate during that time step. If a larva survived physiological stress, it would grow from age 0 at hatching to age 4 at the moult to megalopa, corresponding to stages zoeae 1 to 4 ; megalopae lived and remained competent until age 5 and then died. No other temporally or spatially distributed source of mortality (e.g. predation) was used because of lack of information.

The choice of some of the parameters and behaviours used in the present study was supported by the Domingues et al. (2011a) study and by several other preliminary experiments. Time steps, $\mathrm{d} t$, smaller than $300 \mathrm{~s}$ always produced identical results in terms of number of larvae supplied to each estuary, while longer time steps introduced changes relative to the results obtained with $300 \mathrm{~s}$, which arose from numerical issues. The time step of $300 \mathrm{~s}$ was, therefore, chosen as a compromise between accuracy and computing time. Several sizes of the larval release and recruitment zones had been tested by Domingues et al. (2011a), by analysing the effect of area size on the predicted supply to the Ria de Aveiro. The intermediate size was the one that best represented observed supply to the Ria de Aveiro (the others were half and double the area). Using that size as a standard, we used similar sizes for all the estuaries. The number of particles used in numerical simulations of dispersal may considerably affect the estimates of long-distance dispersal, because a few particles may be subjected to rare combinations of spatially varying flows (Cowen et al. 2000). In the experiments reported by Domingues et al. (2012), mortality did not appear to affect the patterns of dispersal and supply. These experiments effectively provided an assessment of the effect of varying the number of particles introduced into the model. A larger number of particles could, indeed, result in rare events of long-distance dispersal, but these would not likely affect the average connectivity patterns. Initial tests in one single year with twice the number used in the present study did not seem to result in long-distance dispersal. The final number used in the present study is a compromise to computing and analysis time. Finally, the influence of DVM on the cross-shore distribution of larvae and retention on the shelf had also been tested in the Domingues et al. (2012) study, which showed that the runs with DVM produced cross-shelf distributions of larvae that matched observed concentrations. We, therefore, included DVM in the present study.

\section{Data analysis}

In order to describe the dispersal and connectivity process, some central concepts related to dispersal and accumulation of larvae should be introduced. Whenever we specify dispersal kernel, dispersal from source or supply from source, we are always referring to the process of transport of larvae away from each population or ensemble of populations where they hatched. Conversely, accumulation kernel, accumulation to sink or supply to sink always refers to the process of transport of larvae recruiting into each population or ensemble of populations. In this study, source and sink are operational terms that designate whether a population is emitting or recei- 
ving larvae, and, therefore, do not carry any consideration as to the value of the habitat in question, as they do in Pulliam (1988). Moreover, implicit in the concept of supply is that it always refers to competent larvae (i.e. megalopae) that successfully recruit to any population.

In the present study, we were interested in the inter-annual and spatial patterns of connectivity. To this end, we calculated square connectivity matrices describing the annual accumulated supply of competent larvae from source population $i$ ( $i=1$ to $k$ ) to sink population $j(j=1$ to $l$ ):

$$
\boldsymbol{C}_{Y}=\left(\begin{array}{ccc}
C_{1,1} & \ldots & C_{1,1} \\
\vdots & \ddots & \vdots \\
C_{k, 1} & \cdots & C_{k, 1}
\end{array}\right)
$$

In matrices $\boldsymbol{C}_{y}$, each element was normalised by the total number of larvae hatched from all populations. These matrices formed the basis to calculate a series of descriptors of the dispersal and connectivity processes.

Annual supply from each source population was defined as the number of larvae originating in that population that successfully recruited into any population, normalised by the total number of larvae hatched. This was calculated as the sum of the respective $i$ line of matrix $\boldsymbol{C}_{Y}$ :

$$
\text { Ssource }_{Y_{i}}=\sum_{j=1}^{l} c_{i, j}
$$

Similarly, annual supply to each sink population was defined as the number of larvae that recruit into that population independently of the source population, also normalised by the total number of larvae hatched, and calculated as the sum of the respective $j$ column of matrix $\boldsymbol{C}_{Y}$ :

$$
\operatorname{Ssink}_{Y_{j}}=\sum_{i=1}^{k} c_{i, j}
$$

Additionally, we calculated net supply to each population as the difference between supply from and supply to that population:

$$
\text { Net supply } Y_{Y_{i}}=\text { Ssource }_{Y_{i}}-\operatorname{Ssink}_{Y_{i}}
$$

Dispersal kernels describe propagule dispersal as the probability density function $[P(x)]$ of the number of propagules that recruit as a function of distance from the source. Since the populations considered in this study are not equally spaced along the coast, we first calculated larval dispersal kernels for each source population by re-indexing the connectivity matrices in Eq. (1) relative to distance along the coast, using $50 \mathrm{~km}$ bins. Moreover, because we are interested in realised dispersal, i.e. dispersal by larvae that recruit successfully, dispersal kernels were standardised by dividing each element by the total number of larvae that were produced by that population and that recruited subsequently. This resulted in an annual dispersal kernel for each source population centred on $0 \mathrm{~km}$ and describing the probabilities of supply binned into $50 \mathrm{~km}$ intervals. Finally, we averaged for the ensemble of source populations in order to obtain annual coast-wide dispersal kernels. Since flow along the coast is not stationary, leading to non-uniform dispersal along the coast, and because each population receives larvae from multiple sources, we were also interested in describing the dispersal distances travelled by larvae that were supplied to each population. Therefore, following Aiken et al. (2007), we also calculated accumulation kernels as the distribution of these dispersal distances, in a similar way to the dispersal kernels but standardising by dividing each element of the kernel by the total number of larvae that recruited into that population.

In the above calculations, distances travelled northward were always defined as positive distances, and distances travelled southward as negative distances. Connectivity matrices, dispersal and accumulation kernels and supply from source and to sink populations were calculated for the $9 \mathrm{yr}$ period by averaging the annual values. In order to assess the fit of the dispersal kernels to a Gaussian distribution, we used Chi-square goodness-of-fit tests comparing observed and expected frequency distributions.

Shelf circulation in the western Iberian Peninsula is mostly controlled by along-shore winds. These are related to the intensity of the Azores anticyclone (Wooster et al. 1976, Fiúza et al. 1982) and its associated northerly winds on the one hand, and to the passage of atmospheric cold fronts and its associated southwesterly winds on the other. In order to inspect the influence of inter-annual variation of wind circulation on dispersal and total supply patterns, we correlated annual average dispersal distance against the annual values of the North Atlantic Oscillation (NAO) station-based index (NCAR Earth Systems Laboratory, Climate Data Guide, (https://climatedataguide.ucar.edu/sites/default/files/cas_data_files /asphilli/nao_station_annual.txt). This analysis was performed only on dispersal distances of larvae leaving from source populations. Additionally, we also separately correlated total supply to the ensemble of populations, as well as total supply to the ensemble of populations in the coasts to the north and to the south of the Estremadura Promontory (Fig. 1), against the annual NAO values. Since supply is measured as 
a ratio, supply was arcsine transformed before the analysis.

Larvae hatched from estuaries located close to the east limit of the target domain may be lost from the model during periods of persistent eastward advection, with the probability of loss increasing with decreasing distance of the source population to the limit, which would affect the estimates of supply to the sink populations. The model predicted that less than $0.2 \%$ of the larvae hatched from Muros-Noia and from Mira, the estuaries located on the northern and southern extremes of the west coast, were advected beyond the east limit of the target domain. Since the along-shore flow in the target domain is oscillatory in nature, and assuming that there are no very large flow asymmetries, this value may be taken as an approximation to the maximum contribution of larvae hatched from the estuaries located along the north and south coasts that would be supplied to estuaries on the west coast if they had not been lost from the model domain. The impact of this larval leakage on populations on the north and south coasts cannot be calculated, but its effect on the estimates of larval supply to the array of estuaries located on the west coast is negligible. Therefore, we only provide estimates of dispersal, accumulation and supply for the populations located on the west coast of the Iberian Peninsula, although we include larvae supplied from the remaining populations on the estimates of accumulation and supply.

\section{RESULTS}

\section{Wind stress patterns}

QuikSCAT meridional (along-shore) daily wind stress from 2 sites located off the northwestern $\left(42.5^{\circ} \mathrm{N}, 10.0^{\circ} \mathrm{W}\right)$ and southwestern $\left(37.5^{\circ} \mathrm{N}, 10.0^{\circ} \mathrm{W}\right)$ coasts of the Iberian Peninsula are displayed in Fig. 2 for the first 7 mo of 2001 to 2009. A dominant southward component was present in the north and south sites during the reported period, but several differences in wind stress patterns between the 2 sites are also conspicuous. Episodes of northward wind stress were much more frequent and intense in the northern than in the southern site from January to April. From May onwards, episodes of northward winds were much less frequent in the northern site, but still more common than in the southern site. Overall, the variability of wind stress was smaller in the southern than in the northern site. Important inter-annual variability was also present.

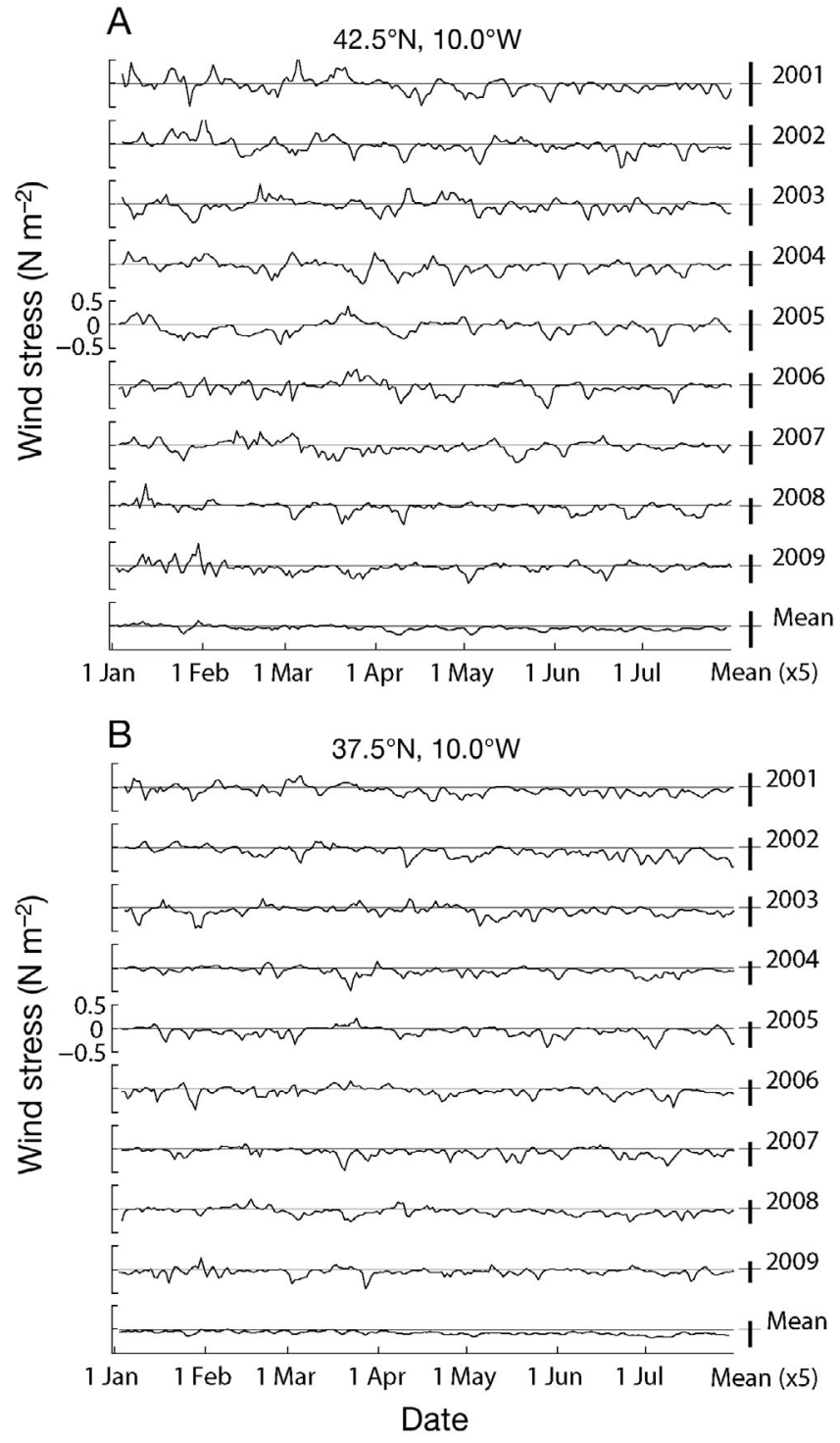

Fig. 2. Daily meridional component of the wind stress for the period January 1 to July 31, for 2001 to 2009, at 2 locations: (A) $42.5^{\circ} \mathrm{N}, 10^{\circ} \mathrm{W}$, and (B) $37.5^{\circ} \mathrm{N}, 10^{\circ} \mathrm{W}$. For each location, the lower plot represents the mean value of wind stress for 2001 to 2009. The mean northward (positive) and southward (negative) wind stress for every year is displayed to the right of every time series (thick vertical lines, thin horizontal lines indicate zero), multiplied by a factor of 5 for better visibility

\section{Dispersal and accumulation kernels}

Average along-shore transport predicted by the model was consistently southward. The only exception to this pattern occurred in 2001, when the model predicted an average northward transport. The model also predicted inter-annual differences in the magnitude of southward dispersal. In 2003, 2005 and 2006, average dispersal and accumulation distances ranged from -5 to $-42 \mathrm{~km}$, but they were consider- 


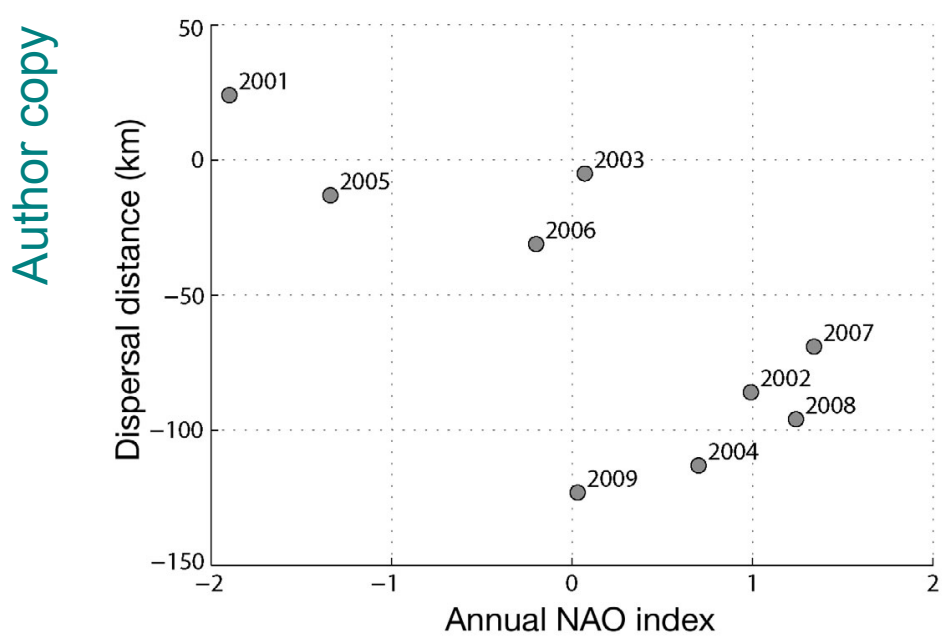

Fig. 3. Influence of the North Atlantic Oscillation (NAO) state on annual average dispersal distance. NAO index values are the station-based annual index. Positive (negative) dispersal distances indicate northward (southward) movement of larvae away from source populations

ably larger in 2002, 2004, 2007, 2008 and 2009, ranging from -69 to $-123 \mathrm{~km}$. In 2001, average dispersal distance was positive at $+24 \mathrm{~km}$. Annual average dispersal distance during the whole 2001 to 2009 period was negatively correlated with the annual NAO index $(\mathrm{r}=-0.74, \mathrm{p}<0.023$, Fig. 3). These transport patterns agree to a large extent with the inter-annual variability of the wind (Fig. 2).

Annual dispersal and accumulations kernels predicted by the model (Figs. 4 \& 5) were asymmetrical and deviated significantly from Gaussian distributions ( $\mathrm{p}<<0.001$ in all cases, according to Chi-square tests), indicating that the dispersal process is strongly influenced by non-homogeneous processes. Moreover, in most cases self-recruitment was higher than predicted from a Gaussian distribution, as indicated by large frequency values of the $0 \mathrm{~km}$ distance class.

\section{Supply from source and into sink populations}

Total supply from source populations (Fig. 6) generally decreased southward for most of the years. Supply from the 3 northern estuaries, and in particular from Vigo $(x=349 \mathrm{~km})$, was consistently higher than supply from the other source populations. Usually, supply from Sado and Mira estuaries, on the southern Portuguese coast, was slightly higher than supply from Tejo, which is located immediately to the north. Total supply into sink populations (Fig. 7) consistently peaked into the Ria de Aveiro $(x=525 \mathrm{~km})$ and/or the Mondego $(x=585 \mathrm{~km})$ estuaries. The only exception to this pattern occurred in 2001, when sup-
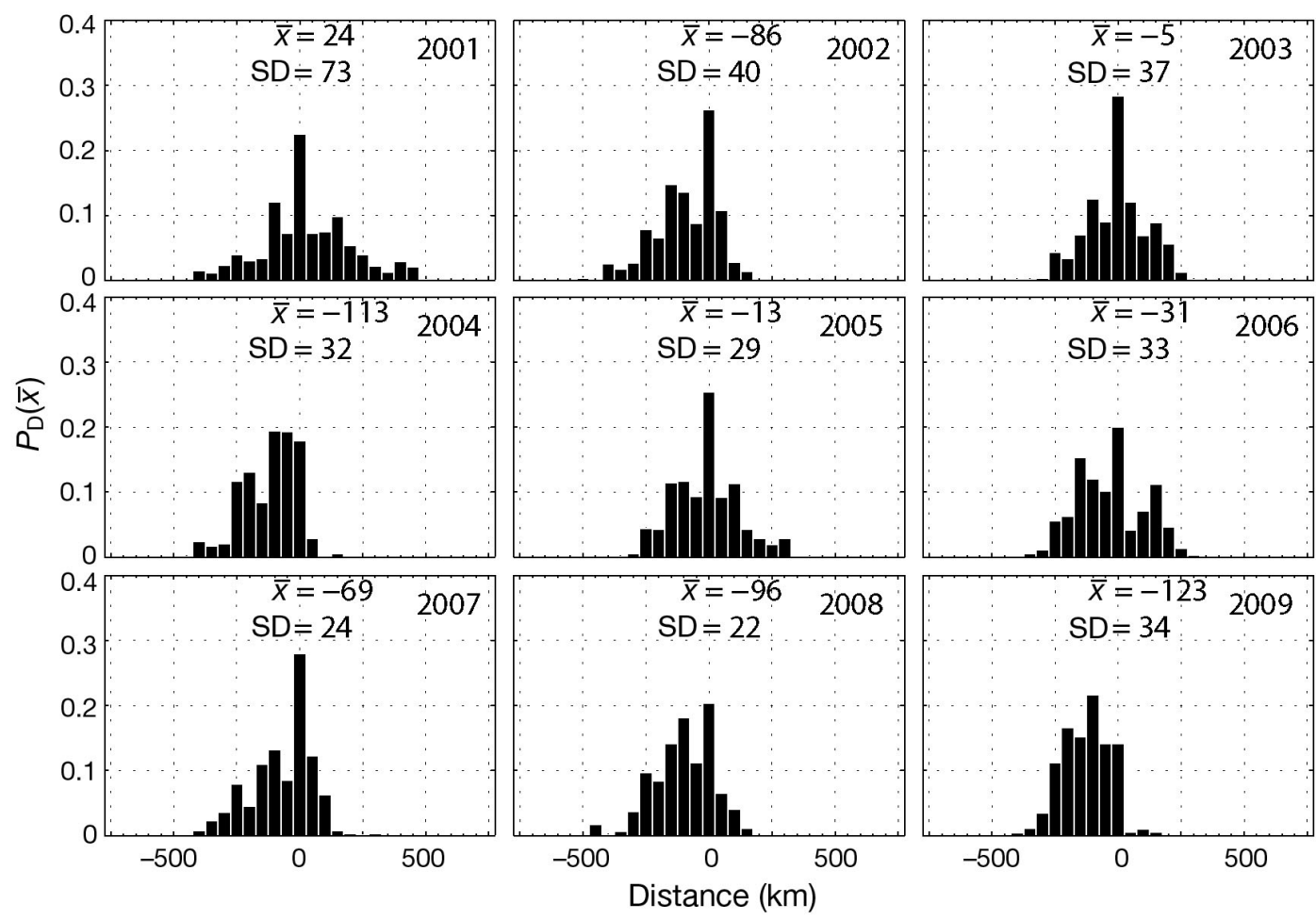

Fig. 4. Annual dispersal kernels $\left[P_{\mathrm{D}}(\mathrm{x})\right]$ predicted by the model. Positive (negative) dispersal distances indicate northward (southward) movement of larvae away from the source population. $\bar{x}=$ average; $\mathrm{SD}=$ standard deviation 

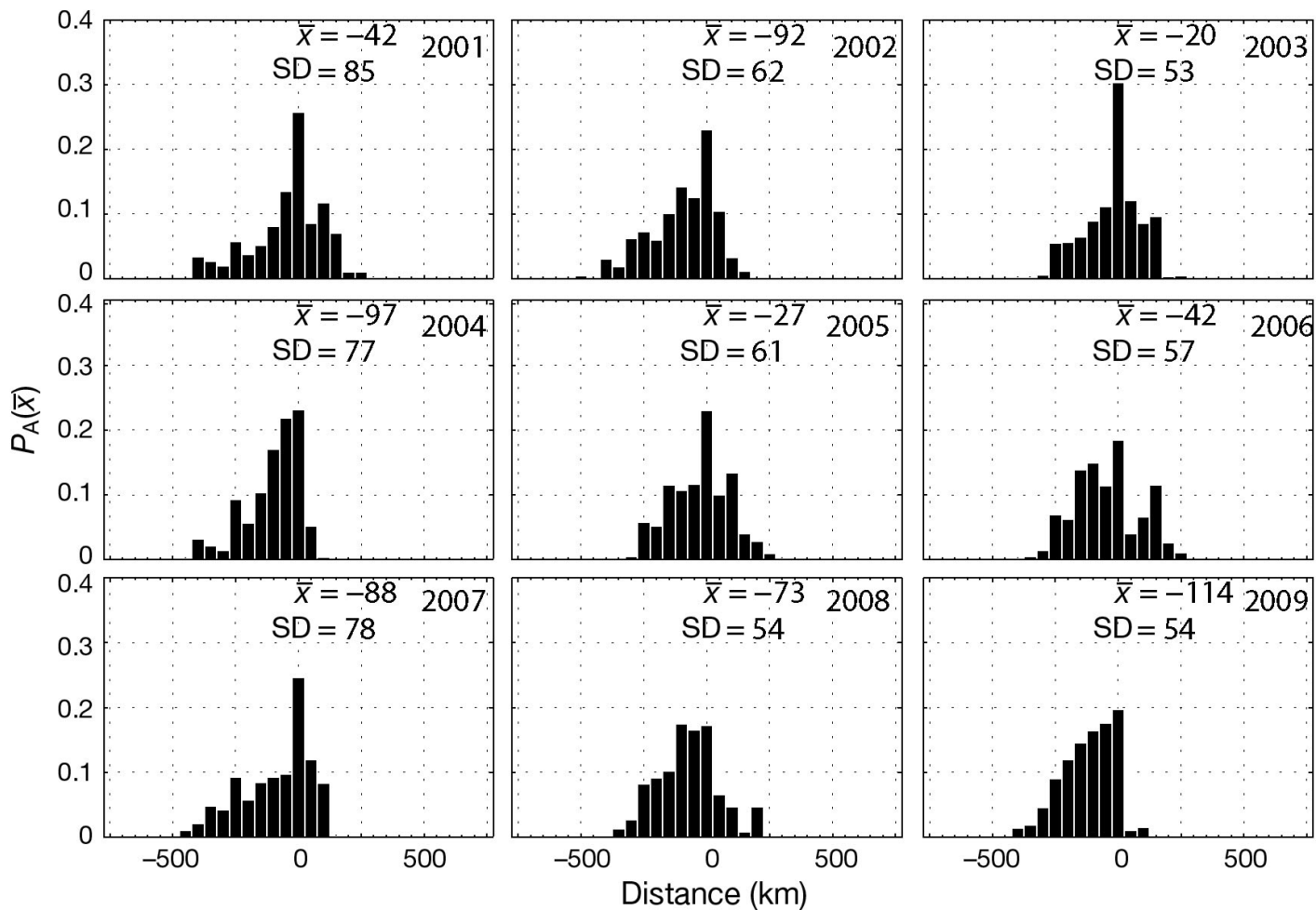

Fig. 5. Annual accumulation kernels $\left[P_{\mathrm{A}}(\mathrm{x})\right]$ predicted by the model. Positive (negative) dispersal distances indicate northward (southward) movement of larvae into the sink population. $\bar{X}=$ average; $\mathrm{SD}=$ standard deviation

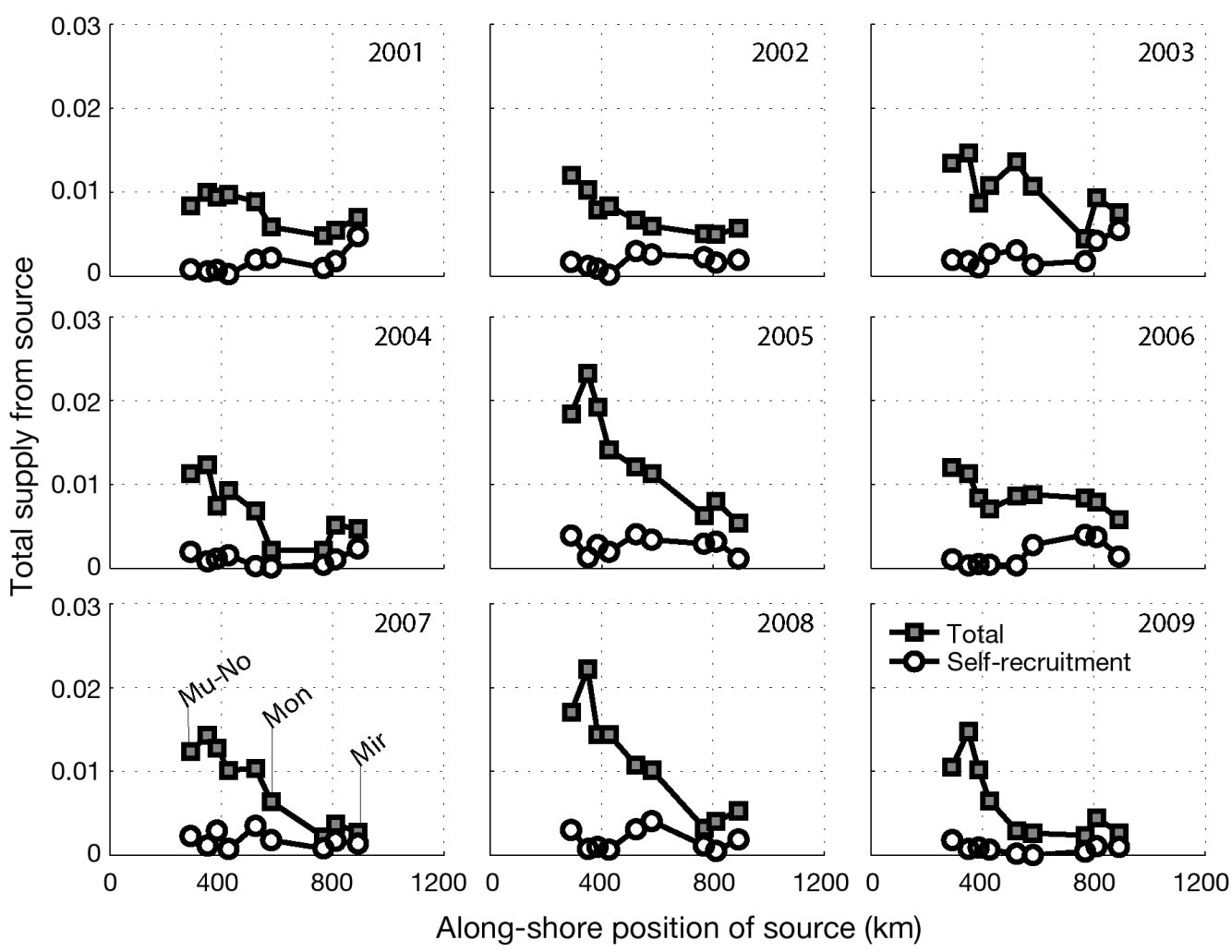

Fig. 6. Total annual supply from each source population as a function of along-shore position of source population. The $x$-axis was arbitrarily set to start at the Navia estuary. The location of Muros-Noia (Mu-No), Mondego (Mon) and Mira (Mir) is indicated for reference 


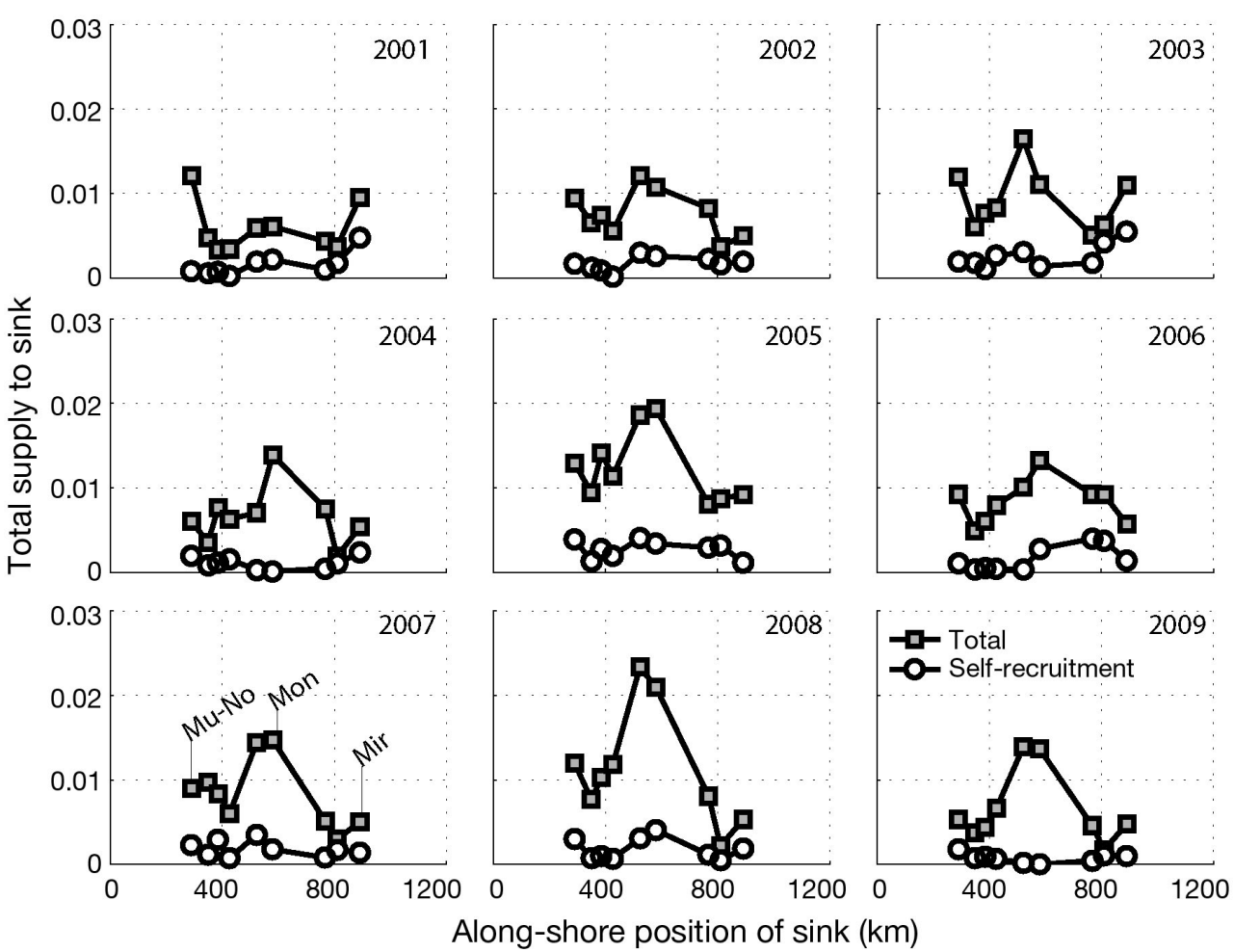

Fig. 7. Total annual supply to each sink population as a function of along-shore position of sink population. The $x$-axis was arbitrarily set to start at the Navia estuary. The location of Muros-Noia (Mu-No), Mondego (Mon) and Mira (Mir) is indicated for reference

ply to Ria de Aveiro and Mondego was below average compared to the whole west coast. Often, supply into the Muros-Noia and the Mira estuaries, located close to the extremes of the west coast, was higher than supply to the adjacent populations. Total supply to the ensemble of populations along the west coast, calculated as the sum of the supply to all the populations in each year, was not correlated with the annual NAO index ( $r=0.07, p>0.848)$. Similarly, supplies to the segments of the coast to the north and to the south of the Estremadura Promontory were uncorrelated with the annual NAO index $(\mathrm{r}=-0.15, \mathrm{p}>0.691$ and $\mathrm{r}=-0.29, \mathrm{p}>0.443$, respectively).

\section{Net supply to each population}

As a result of the trends in supply from source and into sink populations, net supply in the northwest coast was usually higher than in the central and southwest sections of the coast (Fig. 8). Vigo and the other Galician Rias (and to a lesser extent the Minho and the Cávado) acted as net sources of larvae, while the Ria de Aveiro and the Mondego (and to a lesser extent the Tejo) as net sinks. In the Sado and the Mira, net supply oscillated around 0 .

\section{Integrated trends and dispersal matrix}

The trends described above are summarised in Fig. 9, which integrates the whole 9 yr period. Larvae leaving from source populations displayed little average dispersal distances in February and the in first half of March. As the year developed, a trend towards increasing southward transport was predicted (Fig. 9A), as a response to the predominance of northerly winds after the spring transition, starting in April and May (see Fig. 2). Average dispersal for all populations ranged from -15 to $-77 \mathrm{~km}$ (Fig. 9B), whereas average accumulation distance ranged from 0 to $-166 \mathrm{~km}$ (Fig. 9C). The large southward distances travelled by larvae recruiting into the Mondego and, especially, the Tejo estuary were caused by the net southward dispersal along the coast and the large habitat gap between these 2 estuaries. The consequence of the 2 processes is that larvae recruiting into the Mondego came mostly from the north (no larvae from the Tejo and the other estuaries to the south ever reached the Mondego), and that most larvae that recruited into the Tejo originated from this same estuary and from the Ria de Aveiro and the Mondego to the north. Total supply from source populations showed a clear decreasing trend south- 

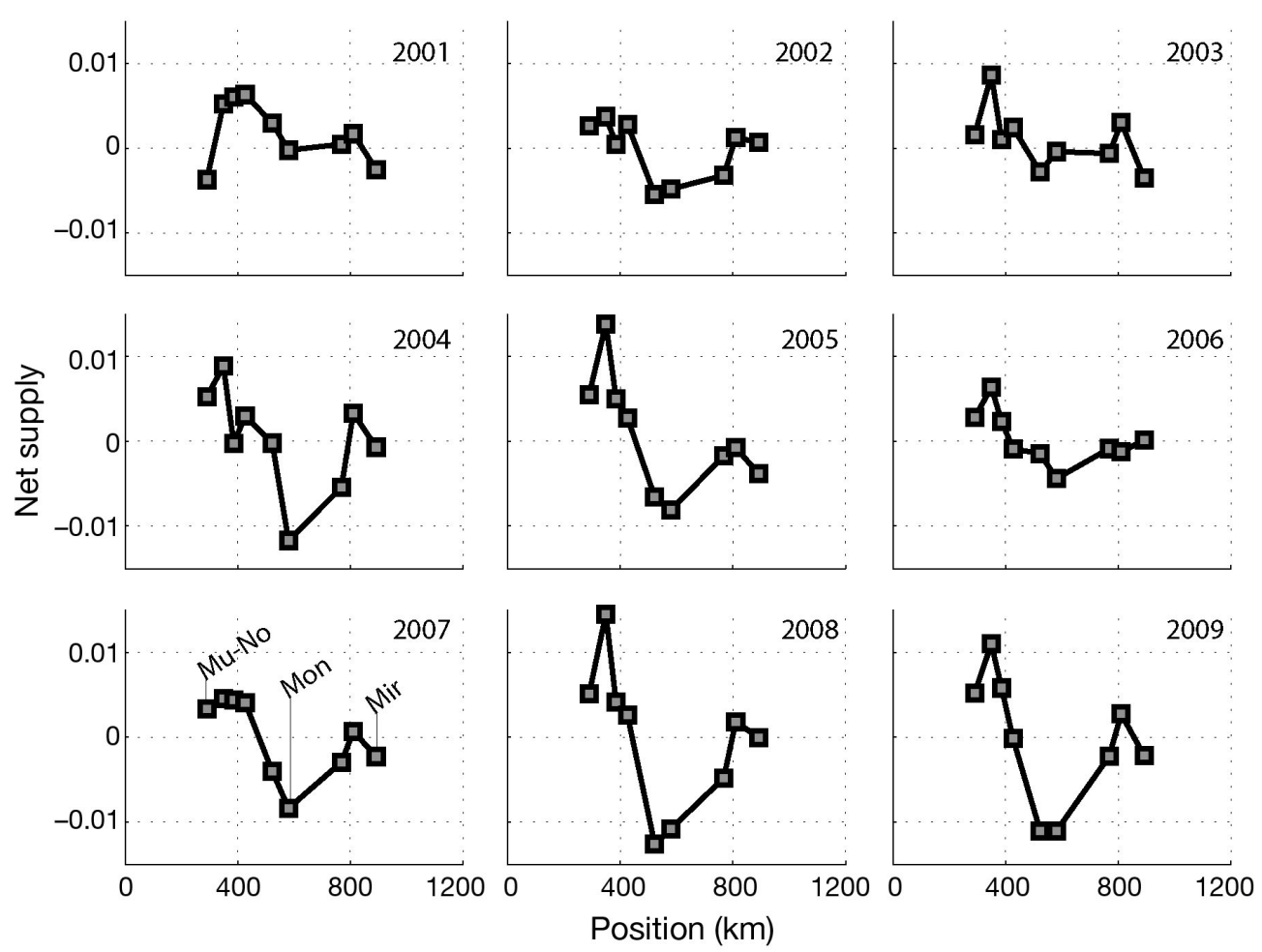

Fig. 8. Net supply as a function of along-shore position of each population. The $x$-axis was arbitrarily set to start at the Navia estuary. The location of Muros-Noia (Mu-No), Mondego (Mon) and Mira (Mir) is indicated for reference

wards, with the Vigo estuary appearing as the largest contributor (Fig. 9D), while total supply to sink populations peaked in the Ria de Aveiro and in the Mondego (Fig. 9E), resulting in contrasting patterns of net supply between the northern group of estuaries, all with positive values, and most of the remaining coast, where net supply is negative except in the Sado estuary Fig. 9F). Both dispersal and accumulation kernels (Fig. 9G,H) departed significantly from Gaussian distributions ( $p<<0.001$ according to Chi-square tests).

The Muros-Noia and Vigo populations, characterised by persistent annual net positive supply, and the Ria de Aveiro and Mondego estuaries, where annual net supply was consistently negative (see Fig. 8), form a source-sink cell in the northwest coast (Fig. 10). Net sources as Vigo and Muros-Noia contributed to populations located as far as $375 \mathrm{~km}$ to the north and $525 \mathrm{~km}$ to the south (Fig. $10 \mathrm{~A}, \mathrm{~B}$ ). Larvae recruiting into net sinks travelled much less. Larvae that recruited into the Ria de Aveiro to the most part originated up to $75 \mathrm{~km}$ to the south or $275 \mathrm{~km}$ to the north, while those supplied to the Mondego all came from the Mondego itself or from northward populations located up to $325 \mathrm{~km}$ away (Fig. $10 \mathrm{C}, \mathrm{D}$ ).

The connectivity matrix for the $9 \mathrm{yr}$ period is represented in Fig. 11. The upper triangular matrix in the figure shows darker greys, indicating an overall ten- dency for dispersal in the equatorward direction (compare with the dispersal kernels shown in Fig. 4). The 9 yr connectivity matrix also shows that the larvae originated from the Tejo and the other southern populations do not recruit into populations located to the north of the Tejo.

\section{DISCUSSION}

In the present study, we used a previously validated biophysical model able to realistically describe the links between dispersal from multiple sources and supply of larvae of the common shore crab (Domingues et al. 2012), in order to investigate how coast-wide patterns of connectivity might be affected by seasonal and inter-annual variability of wind forcing. The predictions of the model strongly suggest several persistent spatial and temporal patterns of connectivity, related to the wind-driven circulation around the Iberian Peninsula, the availability of habitat and the configuration of the coastline. Some of these patterns are non-trivial or counterintuitive, and may be relevant for understanding the ecology of the Iberian coastal ocean and the management of marine biodiversity and resources in the area. 

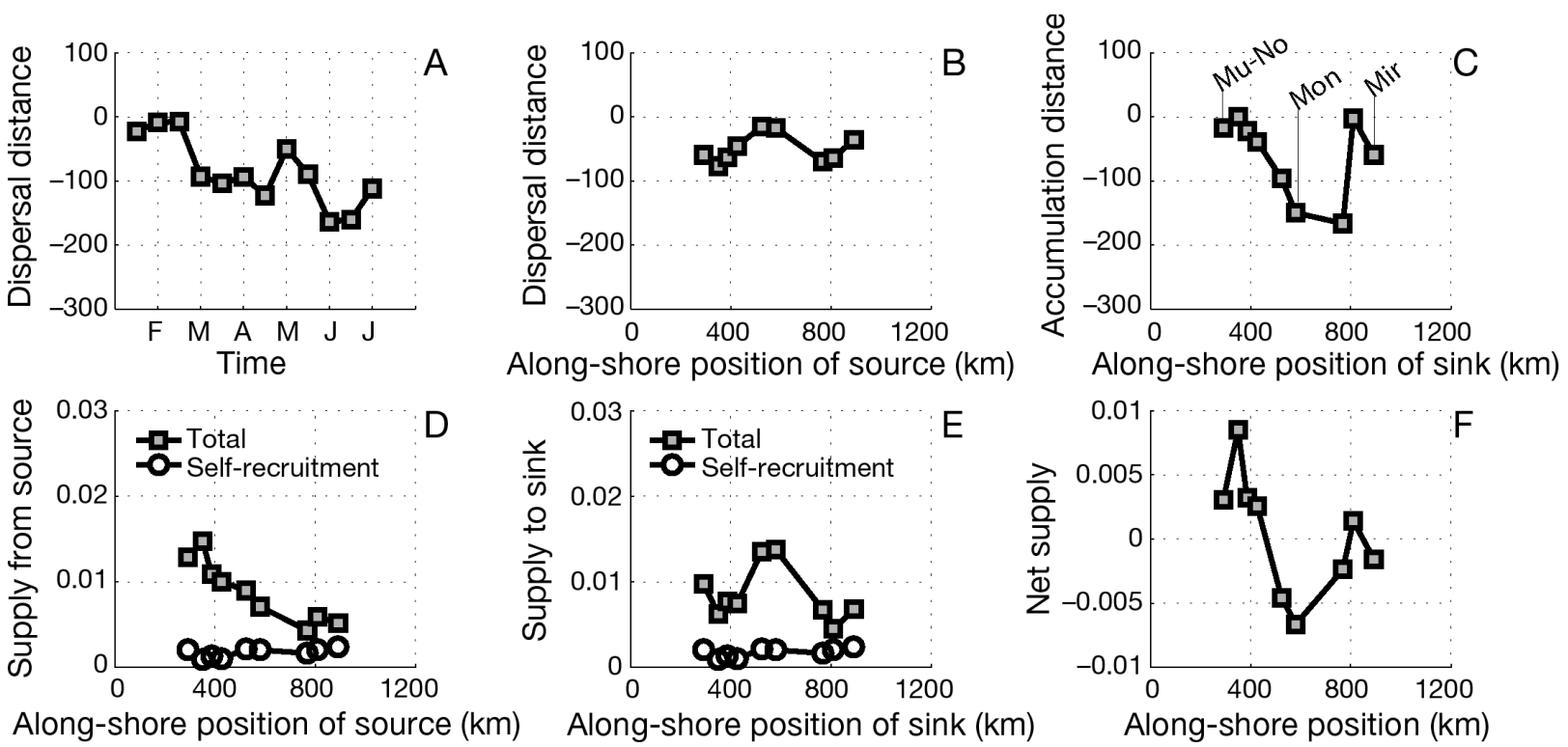

Along-shore position of source $(\mathrm{km})$

Along-shore position of sink $(\mathrm{km})$
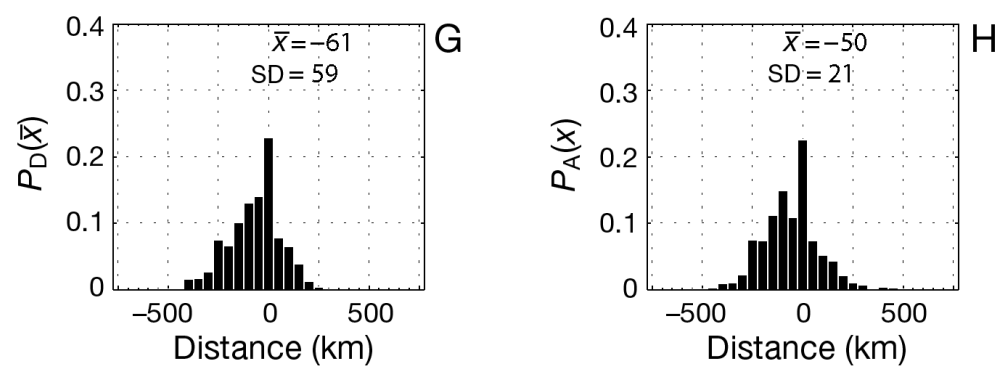

Fig. 9. Statistics of the dispersal and connectivity process integrated for the 9-yr period from 2001 to 2009. (A) Mean dispersal distance for larval hatching event along the season; (B) mean dispersal distance as a function of along-shore position of the source; (C) mean accumulation distance as a function of along-shore position of the sink; (D) total accumulated supply from each source population as a function of along-shore position of the source; (E) total accumulated supply to each sink population as a function of along-shore position of the sink; $(F)$ net supply as a function of along-shore position of each population; $(G)$ mean dispersal kernel $\left[P_{\mathrm{D}}(\bar{x})\right] ;(\mathrm{H})$ mean accumulation kernel $\left[P_{\mathrm{A}}(x)\right] . \bar{x}=$ average; $\mathrm{SD}=$ standard deviation. The location of Muros-Noia (Mu-No), Mondego (Mon) and Mira (Mir) is indicated for reference

\section{Spatial and inter-annual variability of dispersal patterns}

Annual dispersal and accumulation kernels deviated markedly from Gaussian distributions, implying that dispersal does not follow a simple advectiondiffusion model (Largier 2003, Siegel et al. 2003). Most had higher than expected probability densities at $0 \mathrm{~km}$, under Gaussian dispersal, indicating a possible exponential decrease of supply from (to) the source (sink) populations. An exponential decrease of supply would be expected under a constant rate of recruitment through time, which is usually modelled through a Laplace distribution (Neubert et al. 1995). Since the annual dispersal kernels we created result from several episodes of larval production distributed regularly along the reproductive season, it is reasonable to assume a Laplace-type dispersal and supply. However, the kernels we obtained were often poly- modal, which may be a consequence of uneven spacing of the populations along the coast. Given these complexities, we did not attempt to fit other theoretical dispersal kernels to those predicted by the model.

Predicted net dispersal was usually southward during the larval season of Carcinus maenas. This result is consistent with the dominant mode of circulation along the west coast of the Iberian Peninsula during spring and early summer, which is a season dominated by upwelling-favourable winds (Relvas et al. 2007). This equatorward transport was apparent in the dispersal and accumulation kernels of all of the 9 yr except 2001, where the average of the dispersal and accumulation kernels had opposite signs.

The year 2001 was unusual in that it showed extremely strong northward advection during a 3 mo period in late winter, driven by recurrent cold fronts. The passage of cold fronts is associated with south-westerlies and rain in the region, which are 

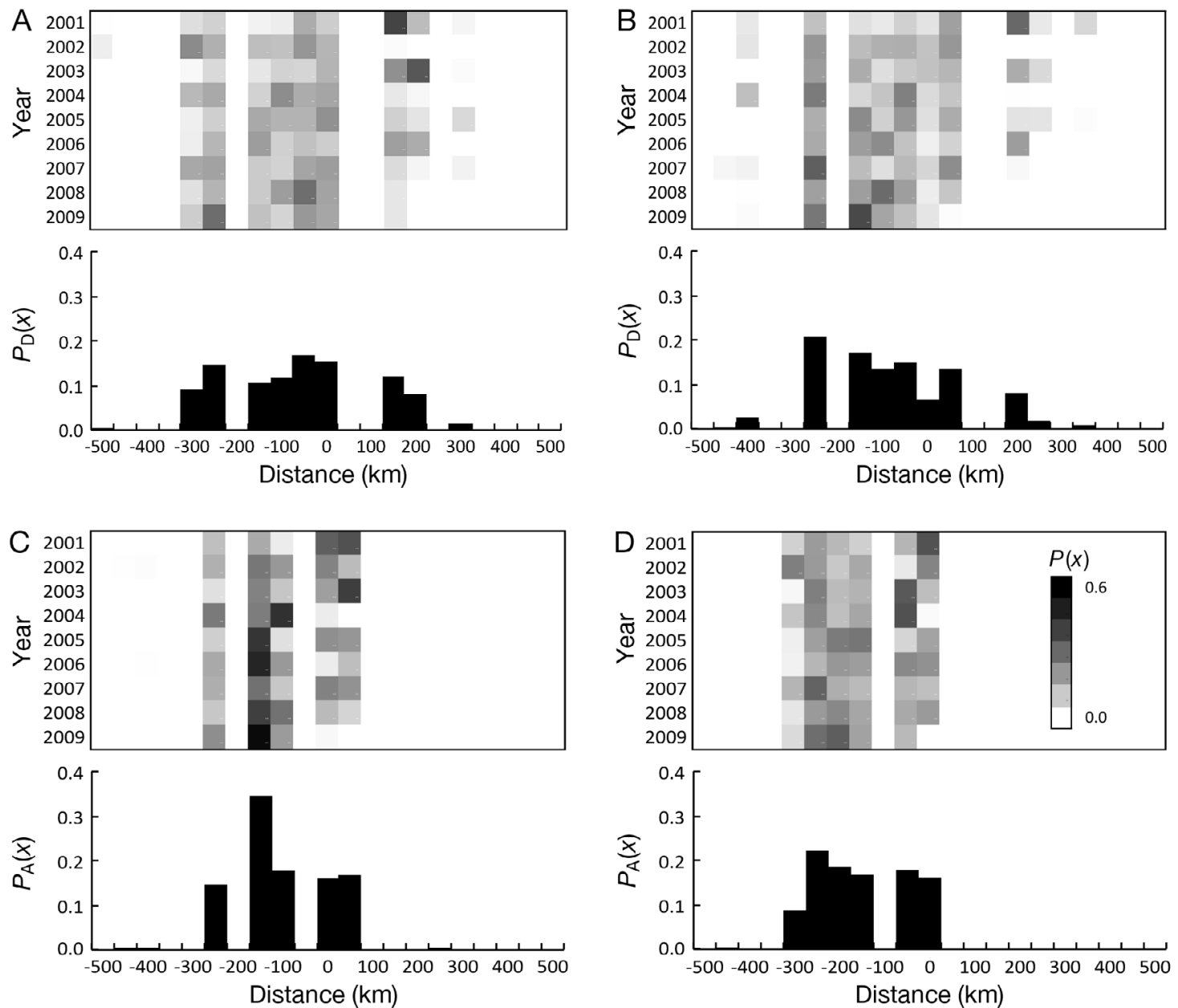

Fig. 10. Dispersal and accumulation kernels for the source-sink cell identified in the northwest coast. (A) Muros-Noia, source: (top) supply from net source as a function of sink distance and year; (bottom) mean dispersal kernel $\left[P_{\mathrm{D}}(\mathrm{x})\right]$ from net source. $(\mathrm{B})$ Vigo, source: (top) supply from net source as a function of sink distance and year; (bottom) mean dispersal kernel from net source. (C) Ria de Aveiro, sink: (top) supply to net sink as a function of source distance and year; (bottom) mean accumulation kernel $\left[P_{\mathrm{A}}(x)\right]$ to net sink. (D) Mondego, sink: (top) supply to net sink as a function of source distance and year; (bottom) mean accumulation kernel to net sink. Key in (D) top panel applies to all top panels. Positive (negative) dispersal distances indicate northward (southward) movements of larva

usually more intense north of the Tejo River. This asymmetrical impact of cold fronts between the north and south coasts of the Iberian Peninsula is a well-known feature of the weather patterns of the region (Relvas et al. 2007), is reflected in the QuikScat winds patterns of Fig. 2 and is documented for the year 2001 (Marta-Almeida et al. 2002). The very strong activity of these fronts in 2001 led to extended periods of wind-driven poleward flow, reinforced by the gravitational flow of extremely large volumes of freshwater discharged by the rivers, especially in the northern section of the west coast. These exceptional weather circumstances were captured by the time series used to force the model. As a result, the predicted flow along the coast was markedly asymmetrical, with a very strong northward transport in the northern section, but little net flow south of the Tejo during late winter and early spring. This situation lead to very large positive dispersal distances of the larvae supplied from the northern estuaries, especially the Mondego and the Ria de Aveiro, which resulted in the positive average of the dispersal kernel (Fig. 4). Larvae hatched from southern estuaries were not subjected to this northward flow. Therefore, the estuaries in the northwest coast were not supplied with larvae originating from the southwestern or northern coasts for an extended period of time. The result of this was the lowest predicted supply to the Mondego and the Ria de Aveiro in the whole $9 \mathrm{yr}$ period (Fig. 7), and a dispersal kernel with a positive average for all of 2001 (Fig. 4). 


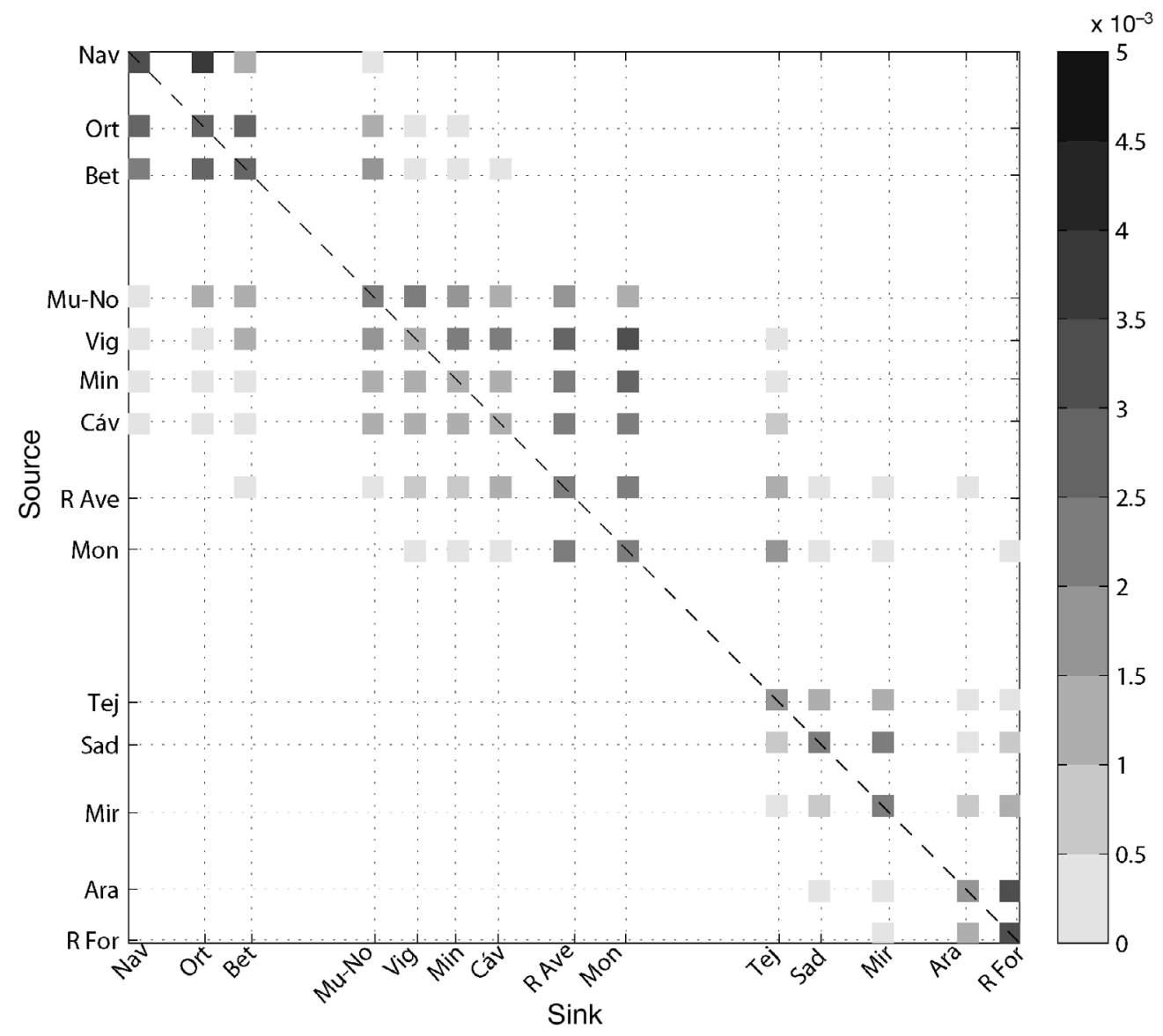

Fig. 11. Connectivity matrix for the estuaries located in the west coast of the Iberian Peninsula, for the 9-yr period from 2001 to 2009. Nav = Navia; Ort $=$ Ortigueira $;$ Bet $=$ Betanzos; Mu-No = Muros-Noia $;$ Vig = Vigo; Min = Minho; Cáv = Cávado; $\mathrm{R}$ Ave $=$ Ria de Aveiro; Mon = Mondego; Tej = Tejo; Sad = Sado; Mir = Mira; Ara = Arade; R For = Ria Formosa. Each line of the matrix represents the distribution of larvae originating from each population that successful recruit to the different populations along the coast. Thus, the diagonal of the connectivity matrix corresponds to the rate of self-recruitment, while the upper (lower) triangular matrix represents dispersal in the equatorward (poleward) direction. Gray scale values are dimensionless and defined as in Eq. (1)

The inter-annual variability of average dispersal length was associated with the annual NAO index. Positive values of the NAO were recorded during 2002, 2004, 2007 and 2008, associated with a clear tendency for equatorward transport as predicted by the model. Positive NAO values are caused by the intensification of the Azores subtropical anticyclone, which promotes an intensification and persistence of equatorward winds and its corresponding southward transport along the western Iberian margin. The only year with a positive average northward transport was 2001, and this was also the year when the lowest NAO value was registered. The frequent passage of low-pressure centres with associated cold fronts and southwest winds, which promote circulation in the northward direction along the shelf, are characteristic of negative NAO values. Intermediate (near-0) NAO values produced more variable results, with predicted average negative transports ranging from close to zero to more than $120 \mathrm{~km}$ (the highest predicted southward transport). The consistence between the annual NAO index and the inter-annual variability of average dispersal length reproduced by the model support its predictive ability, as was verified previously (Domingues et al. 2012).

\section{Connectivity cell}

A non-trivial prediction was the identification in the northwest coast of a contiguous set of populations characterised by persistent inter-annual net positive (Vigo and the other Galician Rias) or negative (Ria de Aveiro and Mondego) supply, indicating the presence of a source-sink cell (Fig. 10). Net sources in this cell were more extensively connected than the net sinks.

That is, the sources supplied larvae to a wide range of populations, while net sinks received larvae from a 
narrower range of populations. An asymmetrical source-sink cell has also been proposed for the southeastern Pacific upwelling system (Aiken et al. 2007), based on a modelling study of passive larval dispersal from equally spaced populations, but in this case the net sinks were more extensively connected than the net sources. Part of the predicted effect in the Iberian coast is caused by the $190 \mathrm{~km}$ gap without estuaries between the Mondego and the Tejo, which decreases successful southward dispersal by larvae lasting 4 to $6 \mathrm{wk}$ in the plankton stage. This habitat gap also constrains the range of coastline where supply from the south is possible during the shorter periods of poleward advection. A lower success of southward dispersers caused by this gap would explain a lower recruitment success of larvae hatched from the Ria de Aveiro and the Mondego, and a supply deficit from the south would cause the short geographical range of successful supply from southward populations. However, these factors do not explain the consistent patterns of higher than average supply to these estuaries (Fig. 7) that result in the accumulation of a surplus of larvae in this section of the coast, nor the shorter range of supply from the north. Therefore, some property of the oceanographic circulation in the region centred in the Ria de Aveiro and Mondego estuaries (Fig. 1) likely contributes to enhanced retention in the area.

Recent investigations into the oceanography of the western Iberian coast (Relvas et al. 2007) suggest a possible explanation to enhanced retention in the area of Ria de Aveiro and Mondego estuaries. An analysis of nearly 2000 sea surface temperature satellite maps for June to September of 2001 to 2005 (Relvas et al. 2007) indicated 3 main coastal upwelling centres along the western Iberian coast, with average temperatures more than $3^{\circ} \mathrm{C}$ cooler than offshore waters. These areas are located between the Minho and Douro estuaries, between the Capes Carvoeiro and Espichel, and between the Capes Sines and S. Vicente (see Fig. 1), and correspond to the sources of the recurrent upwelling filaments characteristic of the Iberian upwelling zone. The higher average temperature off the long stretch of mostly linear coast between the Douro and Cape Carvoeiro identified from this analysis likely results from the cyclonic onshore return flow south of the filament jet that originates from the upwelling source to the north. Relvas et al. (2007) suggest that these recurrent circulation patterns originate a retention zone in this stretch of the coast. This mechanism was identified from observations made during the summer months, while the simulated larval dispersal season extends from February to July. However, the basic mechanism may still apply during much of this period, because of the oscillatory nature of the wind patterns in the region, with frequent episodes of upwelling throughout the year and increasing persistence from March onwards. One of the predictions of the model is that the successfully recruiting larvae do not leave the inner shelf zone and are oscillating along the coast in response to the intensification, relaxation and reversal of the wind events (Domingues et al. 2012), and would not be subjected to extended offshore transport and return to the coast. However, a dampened average equatorward transport in the area of the Ria de Aveiro and Mondego estuaries, caused by the recirculation associated with the upwelling filament, could explain the accumulation of larvae in the area, the predicted net sink pattern and the predicted constrained connectivity of the net sink populations.

\section{Implications for genetic structure}

The patterns and mechanisms of connectivity identified in this study may be relevant for understanding observations of population structure of Carcinus maenas and of other coastal species along the Atlantic coast of the Iberian Peninsula. Adult populations of the shore crab located to the north and south of the Estremadura Promontory sampled in 2005 showed a slight, but significant, genetic differentiation (Pascoal et al. 2009). When these populations were sampled in 2006 and 2007 within a larger study, no signs of genetic structure were found (Domingues et al. 2010) and differences between adult populations and contemporary larval cohorts were also nonexistent (Domingues et al. 2011b). Information on gene flow and phylogeographic structure available for the European Atlantic coast, including the region of the Iberian Peninsula, for several sedentary littoral invertebrate (Duran et al. 2004, Stamatis et al. 2004, Triantafyllidis et al. 2005, Weber \& Hawkins 2006, Couceiro et al. 2007, Diz \& Presa 2008, Sotelo et al. 2008, 2009, Campo et al. 2010) and fish (Francisco et al. 2006, Domingues et al. 2007) species with planktonic larval development times over $2 \mathrm{wk}$ indicates the absence of clear genetic discontinuities in the region. Theoretical studies demonstrate that, in the presence of net along-shore flows, spatial genetic discontinuities in species with moderate planktonic development times can only persist as long as there is some selection favouring the downstream alleles, either because of a spatial gradient in selection, or 
because of along-shore variations in recruitment intensity associated with habitat quality or larval transport (Pringle \& Wares 2007). The majority of the observations for the west coast of the Iberian Peninsula would indicate that selection factors, habitat effects and flow characteristics are not strong enough to maintain genetic clines in this region. Moreover, the frequent current reversals at time scales of 3 to 7 d (Sousa \& Bricaud 1992, Almeida \& Queiroga 2003) and the relatively strong current mean speeds at event scales reaching over $15 \mathrm{~cm} \mathrm{~s}^{-1}$ (Martins et al. 2002) indicate that most of the habitat gaps for rocky shore, sandy shore or estuarine species might be overcome during their planktonic dispersal phase. Since the period of these flow reversals is much shorter than the reproductive season of most species, this would also contribute to a homogenization of genetic frequencies (Byers \& Pringle 2006). Yet, the fact that $C$. maenas shows slight instabilities in the spatial genetic structure might be linked to the habitat gap north of the Tejo, to a possible retention effect or to the inter-annual variability of larval transport. Temporal genetic variation is a common feature of marine populations (Selkoe et al. 2008) and is likely to be unveiled as data accumulate (Kordos \& Burton 1993, Nielsen et al. 2004, Pujolar et al. 2006, Selkoe et al. 2006) and better descriptions of dispersal, habitat quality and selection become available.

If the predictions on the general mechanisms and extent of Carcinus maenas larval dispersal made by the present model do represent the main trends of larval dispersal and population connectivity of species with similar larval ecologies around the Iberian Peninsula, then it appears that the absence of genetic structure in these populations derives from a lack of major barriers to along-shore larval dispersal in this area. This situation contrasts with the deep phylogeographic breaks identified in California, a region also affected by upwelling where genetic discontinuities cluster around the Los Angeles and the Monterey Bay areas (reviewed by Dawson 2001, Pelc et al. 2009). These breaks are proposed to be maintained by ancient discontinuities in current patterns, habitat gaps and temperature regimes influencing larval dispersal and selection, which would not have been affected much by the sea level and climate changes that took place through the Pleistocene and Holocene (Dawson 2001). Much less data are available from the upwelling system of the northeast Atlantic than from its counterpart in the northeast Pacific, but the apparent contrast between these 2 regions regarding the prevalence of genetic structure indicates differences in the physical and geo- logical background between these 2 upwelling areas, stressing the need for and interest in a comparative study between the 2 systems.

\section{Implications for colonisation of invaded regions}

Carcinus maenas has invaded several regions of the world since the end of the 19th century (Carlton \& Cohen 2003, Darling et al. 2008) and is included in the IUCN list of the 100 most dangerous invasive species. Range expansion, mediated by larval dispersal, is reported in some of the invaded regions (Yamada \& Kosro 2009, Thresher et al. 2003). Some of these range expansions are associated with infrequent events (within the species generation time). For instance, along the coasts of the northeast Pacific, northward spread has been reported during El Niño years characterised by poleward flows, which are opposite to the dominant equatorward flow of normal years. The results of the present modelling study indicate average annual dispersal distances that may exceed $100 \mathrm{~km}$. During the 9 yr of simulations, a few larvae successfully dispersed up to $540 \mathrm{~km}$ from the source populations in either direction (not shown), concurrently with long periods of especially intense wind events. Given these dispersal estimates and the possibility of still longer-range transport during extreme events with larger return periods, spread of the species in the invaded regions is not likely to be limited by larval dispersal alone, except perhaps in regions with strong and persistent hydrographical barriers (Gaylord \& Gaines 2000, Dawson 2001, Pelc et al. 2009).

Acknowledgements. This work is part of the 'ISCAD - Inner shelf circulation and dispersion patterns: Interactions with estuarine systems' (PTDC/MAR/65760/2006) and 'LarvalSources - Assessing the ecological performance of marine protected area (MPA) networks' (PTDC/BIA-BIC/120483/ 2010) research projects, funded by the Fundação para a Ciência e Tecnologia (FCT) under the European Regional Development Fund. FCT also supported PhD grants to C.P.D. (SFRH/BD/21593/2005), A.C.P. (SFRH/BD/47500/ 2008) and R.N. through Programa Ciencia 2007. This work is also a contribution to the RAIA project (0313_RAIA_1_E) funded by POCTEP and FEDER. Many thanks to the anonymous reviewers and the editorial assistant for their careful reading and editorial work.

\section{LITERATURE CITED}

Aiken CM, Navarrete SE, Castillo MI, Castilla JC (2007) Along-shore larval dispersal kernels in a numerical ocean model of the central Chilean coast. Mar Ecol Prog Ser 339:13-24 
Almeida MJ, Queiroga H (2003) Physical forcing of onshore transport of crab megalopae in the northern Portuguese upwelling system. Est Coast Shelf Sci 57:1091-1102

Almeida MJ, Flores A, Queiroga H (2008) Effect of crab size and habitat type on the locomotory activity of juvenile shore crabs, Carcinus maenas. Est Coast Shelf Sci 80: 509-516

> Becker BJ, Levin LA, Fodrie FJ, McMillan PA (2007) Complex larval connectivity patterns among marine invertebrate populations. Proc Natl Acad Sci USA 104: 3267-3272

> Botsford LW, Moloney CL, Hastings A, Largier JL, Powell TM, Higgins K, Quinn JF (1994) The influence of spatially and temporally varying oceanographic conditions on meroplanktonic metapopulations. Deep-Sea Res 41: 107-145

Byers JE, Pringle JM (2006) Going against the flow: retention, range limits and invasions in advective environments. Mar Ecol Prog Ser 313:27-41

> Cacabelos E, Lourido A, Troncoso JS (2010) Composition and distribution of subtidal and intertidal crustacean assemblages in soft-bottoms of the Ria de Vigo (NW Spain). Sci Mar 74:455-464

Caley MJ, Carr MH, Hixon MA, Hughes TP, Jones GP, Menge BA (1996) Recruitment and the local dynamics of open marine populations. Annu Rev Ecol Syst 27: 477-500

> Campo D, Molares J, Garcia L, Fernandez-Rueda P, GarciaGonzalez C, Garcia-Vazquez E (2010) Phylogeography of the European stalked barnacle (Pollicipes pollicipes): identification of glacial refugia. Mar Biol 157:147-156

Carlton JT, Cohen AN (2003) Episodic global dispersal in shallow water marine organisms: the case history of the European shore crabs Carcinus maenas and C. aestuarii. J Biogeogr 30:1809-1820

Carr SD, Capet XJ, McWilliams JC, Pennington JT, Chavez FP (2007) The influence of diel vertical migration on zooplankton transport and recruitment in an upwelling region: estimates from a coupled behavioral-physical model. Fish Oceanogr 17:1-15

Conkright M, Locarnini R, Garcia H, O'Brien T, Boyer T, Stephens C, Antonov J (2002) World Ocean Atlas 2001: objective analyses, data statistics and figures. National Oceanographic Data Center Internal Report 17. US Dept. of Commerce, Silver Spring, MD

> Couceiro L, Barreiro L, Ruiz JM, Sotka EE (2007) Genetic isolation by distance among populations of the netted dog whelk Nassarius reticulatus (L.) along the European Atlantic coastline. J Hered 98:603-610

Cowen RK, Lwiza KMM, Sponaugle S, Paris CB, Olson DB (2000) Connectivity of marine populations: open or closed? Science 287:857-859

Crothers J (1970) The distribution of crabs on rocky shores around the Dale Peninsula. Field Stud 3:263-274

da Silva A, Young C, Levitus S (1994) Atlas of Surface Marine Data 1994, Vol 1: algorithms and procedures. NOAA Atlas NEDIS 6, US Dept. of Commerce, Washington, DC

> Darling JA, Baglry MJ, Roman J, Tepolt CK, Geller JB (2008) Genetic patterns accross multiple introductions of the globally invasive crab genus Carcinus. Mol Ecol 17: 4992-5007

Dawirs RR (1985) Temperature and larval development of Carcinus maenas (Decapoda) in the laboratory; predictions of larval dynamics in the sea. Mar Ecol Prog Ser 24: 297-302
Dawson MN (2001) Phylogeography in coastal marine animals: a solution from California. J Biogeogr 28:723-736

> Diz AP, Presa P (2008) Regional patterns of microsatellite variation in Mytilus galloprovincialis from the Iberian Peninsula. Mar Biol 154:277-286

Doherty PJ, Planes S, Mather P (1995) Gene flow and larval duration in 7 species of fish from the Great Barrier Reef. Ecology 76:2373-2391

> Domingues VS, Faria C, Stefanni S, Santos RS, Brito A, Almada VC (2007) Genetic divergence in the AtlanticMediterranean Montagu's blenny, Coryphoblennius galerita (Linnaeus 1758) revealed by molecular and morphological characters. Mol Ecol 16:3592-3605

> Domingues CP, Creer S, Taylor MI, Queiroga H, Carvalho GR (2010) Genetic structure of Carcinus maenas within its native range: larval dispersal and oceanographic variability. Mar Ecol Prog Ser 410:111-123

> Domingues CP, Almeida MJ, Dubert J, Nolasco R and others (2011a) Supply of crab larvae to an estuary in the eastern Atlantic upwelling system exhibits predictable and haphazard variation at different temporal scales. Mar Ecol Prog Ser 425:113-124

> Domingues CP, Creer S, Taylor MI, Queiroga H, Carvalho GR (2011b) Temporal genetic homogeneity among shore crab (Carcinus maenas) larval events supplied to an estuarine system on the Portuguese northwest coast. Heredity 106:832-840

> Domingues CP, Nolasco R, Dubert J, Queiroga H (2012) Model-derived dispersal pathways from multiple source populations explain variability of invertebrate larval supply. PLoS ONE 7:e35794

$>$ dos Santos A, Santos AMP, Conway DVP, Bartilotti C, Lourenço P, Queiroga H (2008) Diel vertical migration of decapod larvae in the Portuguese coastal upwelling ecosystem: implications for offshore transport. Mar Ecol Prog Ser 359:171-183

> Duran S, Palacín C, Becerro MA, Turon X, Giribet G (2004) Genetic diversity and population structure of the commercially harvested sea urchin Paracentrotus lividus (Echinodermata, Echinoidea). Mol Ecol 13:3317-3328

Ellien C, Thiébaut E, Dumas F, Salomon JC, Nival P (2004) A modelling study of the respective role of hydrodynamic processes and larval mortality on larval dispersal and recruitment of benthic invertebrates: example of Pectinaria koreni (Annelida: Polychaeta) in the Bay of Seine (English Channel). J Plankton Res 26:117-132

Erftemeijer PLA, van Beek JKL, Bolle LJ, Dickey-Collas M, Los HFJ (2009) Variability in transport of fish eggs and larvae. I. Modelling the effects of coastal reclamation. Mar Ecol Prog Ser 390:167-181

Fiúza A (1983) Upwelling patterns off Portugal. In: Suess J, Thiede E (eds) Coastal upwelling: its sediment record. Part A. Plenum, New York, NY, p 85-98

Fiúza A, Macedo M, Guerreiro M (1982) Climatological space and time variation on the Portuguese coastal upwelling. Oceanol Acta 5:31-40

> Flores AV, Paula J (2001) Intertidal distribution and species composition of brachyuran crabs at 2 rocky shores in Central Portugal. Hydrobiologia 449:171-177

> Francisco SM, Vieira MN, Almada VC (2006) Genetic structure and historical demography of the shanny Lipophrys pholis in the Portuguese coast based on mitochondrial DNA analysis. Mol Phylogenet Evol 39:288-292

> Frouin R, Fiúza AFG, Ambar I, Boyd TJ (1990) Observations of a poleward surface current off the coasts of Portugal 
and Spain during winter. J Geophys Res C 95:679-691

> Galindo HM, Pfeiffer-Herbert AS, McManus MA, Chao YI, Chai FEI, Palumbi SR (2010) Seascape genetics along a steep cline: using genetic patterns to test predictions of marine larval dispersal. Mol Ecol 19:3692-3707

Gaylord B, Gaines SD (2000) Temperature or transport? Range limits in marine species mediated solely by flow. Am Nat 155:769-789

Gomes V (1991) O caranguejo Carcinus maenas (L.) da Ria de Aveiro: dados sobre o valor económico, avaliação dostock e esforço de pesca. In: Seminário Eurocoast - A zona costeira e os probemas ambientais. Aveiro University Press, Aveiro, p 159-166

Haynes R, Barton ED, Pilling I (1993) Development, persistence, and variability of upwelling filaments off the Atlantic coast of the Iberian Peninsula. J Geophys Res C 98:22681-22692

Hellberg ME (1994) Relationships between inferred levels of gene flow and geographic distance in a philopatric coral, Balanophyllia elegans. Evolution 48:1829-1854

Huthnance JM, Van Aken HM, White M, Barton ED and others (2002) Ocean margin exchange - water flux estimates. J Mar Syst 32:107-137

Incze LS, Wahle RA, Palma AT (2000) Advection and settlement rates in a benthic invertebrate: recruitment to first benthic stage in Homarus americanus. ICES J Mar Sci 57:430-437

> James MK, Armsworth PR, Mason LB, Bode L (2002) The structure of reef fish metapopulations: modelling larval dispersal and retention patterns. Proc R Soc Lond B Biol Sci 269:2079-2086

> Junoy J, Viéitez JM (1990) Macrozoobenthic community structure in the Ría de Foz, an intertidal estuary (Galicia, Northwest Spain). Mar Biol 107:329-339

Kordos LM, Burton RS (1993) Genetic differentiation of Texas Gulf Coast populations of the blue crab Callinectes sapidus. Mar Biol 117:227-233

Largier JL (2003) Considerations in estimating larval dispersal distances from oceanographic data. Ecol Appl 13: 71-89

> Levin LA (2006) Recent progress in understanding larval dispersal: new directions and digressions. Integr Comp Biol 46:282-297

Marta-Almeida M, Dubert J (2006) The structure of tides in the Western Iberian region. Cont Shelf Res 26:385-400

Marta-Almeida M, Peliz A, Dubert J (2002) Simulations of extreme shelf current along the north-western Iberian shelf forced by wind and river runoff. In: Proceedings of the Iberian Meeting on Geophysics and Geodesy, Febr 4-8, 2002, Valencia, p 1555-1559

- Marta-Almeida M, Dubert J, Peliz A, Queiroga H (2006) Influence of vertical migration pattern on retention of crab larvae in a seasonal upwelling system. Mar Ecol Prog Ser 307:1-19

Martins CS, Hamann M, Fiúza AFG (2002) Surface circulation in the eastern North Atlantic, from drifters and altimetry. J Geophys Res C 107:3217, doi: 10.1029/2000 $\mathrm{JC} 000345$

Metaxas A, Saunders M (2009) Quantifying the 'bio-' components in biophysical models of larval transport in marine benthic invertebrates: advances and pitfalls. Biol Bull (Woods Hole) 216:257-272

> Miller TJ (2007) Contribution of individual-based coupled physical-biological models to understanding recruitment in marine fish populations. Mar Ecol Prog Ser 347:
$127-138$

Mitarai S, Siegel DA, Winters KB (2008) A numerical study of stochastic larval settlement in the California Current system. J Mar Syst 69:295-309

> Mohamedeen H, Hartnoll RG (1990) Larval and postlarval growth of individually reared specimens of the common shore crab Carcinus maenas (L.). J Exp Mar Biol Ecol 134:1-24

Morgan SG (1995) Life and death in the plankton: larval mortality and adaptation. In: McEdward L (ed) Ecology of marine invertebrate larvae. CRC Press, Boca Raton, FL, p 279-321

Nagaraj M (1993) Combined effects of temperature and salinity on the zoeal development of the green crab, Carcinus maenas (Linnaeus, 1758) (Decapoda: Portunidae). Sci Mar 57:1-8

Neubert MG, Kot M, Lewis MA (1995) Dispersal and pattern formation in a discrete-time predator-prey model. Theor Popul Biol 48:7-43

> Neves A, Cabral HN, Gordo LS (2007) Distribution and abundance patterns of decapod crustaceans in the Sado estuary, Portugal. Crustaceana 80:97-112

> Nielsen EE, Nielsen PH, Meldrup D, Hansen MM (2004) Genetic population structure of turbot (Scophthalmus maximus L.) supports the presence of multiple hybrid zones for marine fishes in the transition zone between the Baltic Sea and the North Sea. Mol Ecol 13:585-595

> Oliveira PB, Nolasco R, Dubert J, Moita T, Peliz Á (2009) Surface temperature, chlorophyll and advection patterns during a summer upwelling event off central Portugal. Cont Shelf Res 29:759-774

Paris CB, Cowen RK (2004) Direct evidence of a biophysical retention mechanism for coral reef fish larvae. Limnol Oceanogr 49:1964-1979

Pascoal S, Creer S, Taylor MI, Queiroga H, Carvalho G, Mendo S (2009) Development and application of microsatellites in Carcinus maenas: genetic differentiation between Northern and Central Portuguese populations. PLoS ONE 4:e7268

> Pelc RA, Warner RR, Gaines SD (2009) Geographical patterns of genetic structure in marine species with contrasting life histories. J Biogeogr 36:1881-1890

> Peliz A, Rosa TL, Santos AMP, Pissarra JL (2002) Fronts, jets, and counterflows in the Western Iberian upwelling system. J Mar Syst 35:61-77

Peliz Á, Dubert J, Haidvogel DB, Le Cann B (2003) Generation and unstable evolution of a density-driven Eastern Poleward Current: The Iberian Poleward Current. J Geophys Res C 108:3268

> Peliz A, Dubert J, Santos AMP, Oliveira PB, Le Cann B (2005) Winter upper ocean circulation in the Western Iberian Basin. Fronts, eddies and poleward flows: an overview. Deep-Sea Res I 52:621-646

Peliz A, Dubert J, Marchesiello P, Teles-Machado A (2007a) Surface circulation in the Gulf of Cadiz: model and mean flow structure. J Geophys Res C 112:C11015, doi: 10.1029/2002JC001443

> Peliz A, Marchesiello P, Dubert J, Marta-Almeida M, Roy C, Queiroga H (2007b) A study of crab larvae dispersal on the Western Iberian Shelf: physical processes. J Mar Syst 68:215-238

> Pfeiffer-Herbert AS, McManus MA, Raimondi PT, Chao Y, Chai F (2007) Dispersal of barnacle larvae along the central California coast: a modeling study. Limnol Oceanogr 52:1559-1569 
Pineda J, Hare JA, Sponaugle S (2007) Larval transport dispersal in the coastal ocean and consequences for population connectivity. Oceanography 20:22-39

Poulin E, Palma AT, Leiva G, Narvaez D, Pacheco R, Navarrete SA, Castilla JC (2002) Avoiding offshore transport of competent larvae during upwelling events: the case of the gastropod Concholepas concholepas in Central Chile. Limnol Oceanogr 47:1248-1255

Pringle JM, Wares JP (2007) Going against the flow: maintenance of alongshore variation in allele frequency in a coastal ocean. Mar Ecol Prog Ser 335:69-84

Pujolar JM, Maes GE, Volckaert FAM (2006) Genetic patchiness among recruits in the European eel Anguilla anguilla. Mar Ecol Prog Ser 307:209-217

Pulliam R (1988) Sources, sinks, and population regulation. Am Nat 132:652-661

Queiroga H (1995) Processos de dispersão e recrutamento das larvas do caranguejo Carcinus maenas (L.) na Ria de Aveiro. PhD thesis, Universidade de Aveiro

> Queiroga H (1996) Distribution and drift of the crab Carcinus maenas (L.) (Decapoda, Portunidae) larvae over the continental shelf off northern Portugal in April 1991. J Plankton Res 18:1981-2000

Queiroga H, Costlow JD, Moreira MH (1994) Larval abundance patterns of Carcinus maenas (Decapoda, Brachyura) in Canal de Mira (Ria de Aveiro, Portugal). Mar Ecol Prog Ser 111:63-72

> Queiroga H, Costlow JD, Moreira MH (1997) Vertical migration of the crab Carcinus maenas first zoea in an estuary: implications for tidal stream transport. Mar Ecol Prog Ser 149:121-132

> Queiroga H, Almeida MJ, Alpuim T, Flores AAV and others (2006) Tide and wind control of megalopal supply to estuarine crab populations on the Portuguese west coast. Mar Ecol Prog Ser 307:21-36

Relvas P, Barton ED (2005) A separated jet and coastal counterflow during upwelling relaxation off Cape São Vicente (Iberian Peninsula). Cont Shelf Res 25:29-49

Relvas P, Barton ED, Dubert J, Oliveira PB, Peliz A, Silva JCB, Santos AMP (2007) Physical oceanography of the western Iberia ecosystem: latest views and challenges. Prog Oceanogr 74:149-173

Rice AL, Ingle RW (1975) The larval development of Carcinus maenas (L.) and C. mediterraneus Czerniavsky (Crustacea, Brachyura, Portunidae) reared in the laboratory). Bull Br Mus (Nat Hist) Zool 28:101-119

Roughgarden J, Iwasa Y, Baxter C (1985) Demographic theory for an open marine population with space-limited recruitment. Ecology 66:54-67

Roughgarden J, Pennington J, Stoner D, Alexander S, Miller K (1991) Collisions of upwelling fronts with the intertidal zone: the cause of recruitment pulses in barnacle populations of central California. Acta Oecol 12:35-51

Sale PF, Kritzer JP (2003) Determining the extent and spatial scale of population connectivity: decapods and coral reef fishes compared. Fish Res 65:153-172

Selkoe KA, Gaines SD, Caselle JE, Warner RR (2006) Current shifts and kin aggregation explain genetic patchiness in fish recruits. Ecology 87:3082-3094

Selkoe KA, Henzler CM, Gaines SD (2008) Seascape genetics and the spatial ecology of marine populations. Fish Fisheries 9:363-377

Editorial responsibility: Steven Morgan,

Bodega Bay, California, USA
Shanks AL, Brink L (2005) Upwelling, downwelling, and cross-shelf transport of bivalve larvae: test of a hypothesis. Mar Ecol Prog Ser 302:1-12

Shanks AL, Grantham BA, Carr MH (2003) Propagule dispersal distance and the size and spacing of marine reserves. Ecol Appl 13:159-169

> Shchepetkin AF, McWilliams JC (2005) The regional oceanic modeling system (ROMS): a split-explicit, freesurface, topography-following-coordinate oceanic model. Ocean Model 9:347-404

Shulman MJ, Bermingham E (1995) Early-life histories, ocean currents, and the population genetics of Caribbean reef fishes. Evolution 49:897-910

- Siegel DA, Kinlan BP, Gaylord B, Gaines SD (2003) Lagrangian descriptions of marine larval dispersion. Mar Ecol Prog Ser 260:83-96

Siegel DA, Mitarai S, Costello CJ, Gaines SD, Kendall BE, Warner RR, Winters KB (2008) The stochastic nature of larval connectivity among nearshore marine populations. Proc Natl Acad Sci USA 105:8974-8979

Sotelo G, Morán P, Fernández L, Posada D (2008) Genetic variation of the spiny spider crab Maja brachydactyla in the northeastern Atlantic. Mar Ecol Prog Ser 362:211-223

Sotelo G, Posada D, Morán P (2009) Low-mitochondrial diversity and lack of structure in the velvet swimming crab Necora puber along the Galician coast. Mar Biol 156:1039-1048

Sotka EE, Wares JP, Barth JA, Grosberg RK, Palumbi SR (2004) Strong genetic clines and geographical variation in gene flow in the rocky intertidal barnacle Balanus glandula. Mol Ecol 13:2143-2156

Sousa FM, Bricaud A (1992) Satellite-derived phytoplankton pigment structures in the Portuguese upwelling area. J Geophys Res C 97:11343-11356

> Stamatis C, Triantafyllidis A, Moutou KA, Mamuris Z (2004) Mitochondrial DNA variation in Northeast Atlantic and Mediterranean populations of Norway lobster, Nephrops norvegicus. Mol Ecol 13:1377-1390

Swearer SE, Caselle JE, Lea DW, Warner RR (1999) Larval retention and recruitment in an island population of a coral-reef fish. Nature 402:799-802

Thresher R, Proctor C, Ruiz G, Gurney R and others (2003) Invasion dynamics of the European shore crab, Carcinus maenas, in Australia. Mar Biol 142:867-876

> Triantafyllidis A, Apostolidis AP, Katsares V, Kelly E and others (2005) Mitochondrial DNA variation in the European lobster (Homarus gammarus) throughout the range. Mar Biol 146:223-235

Weber LI, Hawkins LI (2006) Allozymic differentiation among geographically distant populations of Patella vulgata (Mollusca, Patellogastropoda). Hydrobiologia 553: 267-275

> Werner FE, Cowen RK, Paris CB (2007) Coupled biological and physical models: present capabilities and necessary developments for future studies of population connectivity. Oceanography 20:54-69

Wooster WS, Bakun A, McLain DR (1976) The seasonal upwelling cycle along the eastern boundary of the North Atlantic. J Mar Res 34:131-141

> Yamada SB, Kosro PM (2009) Linking ocean conditions to year class strength of the invasive European green crab, Carcinus maenas. Biol Invasions 12:1791-1804

Submitted: August 31, 2012; Accepted: March 2, 2013

Proofs received from author(s): June 13, 2013 